University of Wollongong

Research Online

Faculty of Engineering and Information

Faculty of Engineering and Information

Sciences - Papers: Part A

Sciences

$1-1-2015$

Geometrical method for evaluating the internal instability of granular filters based on constriction size distribution

Buddhima Indraratna

University of Wollongong, indra@uow.edu.au

Jahanzaib Israr

University of Wollongong, ji797@uowmail.edu.au

Cholachat Rujikiatkamjorn

University of Wollongong, cholacha@uow.edu.au

Follow this and additional works at: https://ro.uow.edu.au/eispapers

Part of the Engineering Commons, and the Science and Technology Studies Commons

Research Online is the open access institutional repository for the University of Wollongong. For further information contact the UOW Library: research-pubs@uow.edu.au 


\title{
Geometrical method for evaluating the internal instability of granular filters based on constriction size distribution
}

\author{
Abstract \\ Internal instability occurs when the finer fraction from a well-graded granular soil escapes with the \\ infiltrates, rendering a filter ineffective. Thus far, numerous particle size as well as constriction size \\ distribution-based geometrical methods have been proposed to assess potential internal instability. This \\ paper reports the results from hydraulic tests performed on six granular soils (five well-graded sand- \\ gravel mixtures and medium sand) at different uniformity coefficients and compacted at varying relative \\ density. The study facilitated an objective evaluation of some of the well known published methods, \\ leading to a more realistic interpretation of filtration data based on a revised technique, which accurately \\ demarcates the boundary between internally stable and unstable granular soils. A large body of published \\ data and the current laboratory results were used to validate the proposed criterion for the assessment of \\ internal instability, which is also sensitive to the relative density of the filter that has been ignored in most \\ previous methods.

\section{Disciplines} \\ Engineering | Science and Technology Studies

\section{Publication Details} \\ Indraratna, B., Israr, J. \& Rujikiatkamjorn, C. (2015). Geometrical method for evaluating the internal \\ instability of granular filters based on constriction size distribution. Journal of Geotechnical and \\ Geoenvironmental Engineering, 141 (10), 04015045-1-04015045-14.
}




\section{Geometrical Method for Evaluating the Internal Instability of}

2

3

4 Buddhima Indraratna, BSc (Eng), MSc (Lond.), DIC, PhD (Alberta), FIEAust., FASCE

5 Professor of Civil Engineering, Faculty of Engineering,

6 University of Wollongong, Wollongong City, NSW 2522, Australia

7

8 Jahanzaib Israr, BSc (Eng), MSc (Lhr.)

$9 \mathrm{PhD}$ Candidate, Faculty of Engineering,

10 University of Wollongong, Wollongong NSW 2522, Australia.

11 E-mail: ji797@uowmail.edu.au

12

\section{Cholachat Rujikiatkamjorn, BEng, MEng, PhD}

Associate Professor, Faculty of Engineering, University of Wollongong, Wollongong, NSW 2522, Australia.

E-mail: cholacha@uow.edu.au

Date of Submission:

Submitted to: Journal of Geotechnical and Geoenvironmental Engineering, ASCE

Author for correspondence:

Prof. B. Indraratna

Faculty of Engineering

University of Wollongong

Wollongong, NSW 2522

Australia.

Ph: +61242213046

Fax: +61242213238

Email: indra@uow.edu.au 


\section{Geometrical Method for Evaluating the Internal Instability of}

2

3 Buddhima Indraratna, F.ASCE ${ }^{1}$; Jahanzaib Israr ${ }^{2}$ and Cholachat

\section{Granular Filters based on Constriction Size Distribution}

4 Rujikiatkamjorn ${ }^{3}$

\section{Abstract:}

6 Internal instability occurs when the finer fraction from a well-graded granular soil escapes

7 with the infiltrates, rendering a filter ineffective. Thus far, numerous particle size as well as

8 constriction size distributions based geometrical methods have been proposed to assess

9 potential internal instability. This paper reports the results from hydraulic tests performed on six granular soils (five well-graded sand-gravel mixtures and a medium sand) at different uniformity coefficients and compacted at varying relative density. The study facilitated an objective evaluation of some of the well-known published methods, leading to more realistic interpretation of filtration data on the basis of a revised technique, which accurately demarcates the boundary between internally stable and unstable granular soils. A large body of published data plus the current laboratory results were used to validate the proposed criterion for the assessment of internal instability which is also sensitive to the relative density of the filter that has been ignored in most previous methods.

Author keywords: Internal stability, Granular soils, Relative density, Geometrical methods, Constriction

${ }^{1}$ Professor of Civil Engineering, Faculty of Engineering, Univ. of Wollongong, Wollongong City, NSW 2522,

Australia (corresponding author). E-mail: indra@uow.edu.au 
6 Granular filters are expected to arrest the fine base soils that are eroded from an earth structure

7 (e.g. dam core and subgrade) without clogging. In this respect, its own skeletal structure should 8 remain intact during the entire filtration process. Such filters are termed internally stable and 9 require conformation to an appropriate constriction based retention criterion that has been 10 proven to be effective (Indraratna et al., 2007; Raut and Indraratna, 2008). An internally 11 unstable filter exhibits an opposite response whereby the filtrate erodes the finer fraction, 12 rendering the filter ineffective. Xiao and Shwiyhat (2012) provided experimental evidence of suffusion adversely affecting the physical and geo-mechanical properties of granular filter 14 media. The above problems may be encountered in both natural soil deposits and engineered 15 fills (Li and Fannin, 2008; Smith and Bhatia, 2010; Fourie et al. 1994). Poorly graded 16 (uniform) soils usually do not suffer from internal instability, unlike well-graded or gap-graded 17 granular soils (Kenney and Lau, 1985; Skempton and Brogan, 1994).

19 The phenomenon of internal instability has earned much attention from researchers in the past 20 (e.g. USACE, 1953; Kezdi, 1979; Honjo et al. 1996 etc). The potential of internal instability is 21 believed to be the function of soil gradation for which various geometrical assessment methods 22 have been proposed (e.g. Sherard, 1979; Kenney and Lau, 1985; Burenkova, 1993; Indraratna 23 et al. 2011). However, the onset of internal instability in granular soils is governed by the 24 hydro-mechanical factors (Li and Fannin, 2008; Wan and Fell, 2008). Kezdi (1979) applied 25 Terzaghi's criterion of filter design to a given granular particle size distribution (PSD) after 
1 dividing it into coarser and finer fractions. The division point $D_{f}$ on the curve was chosen

2 repeatedly in search of the maximum value of $r_{f}$, which is the ratio between the representative

3 particle sizes of the coarser filter fraction $D_{15}^{c}$ and the finer base soil fraction $d_{85}^{f}$, respectively

4 (Skempton and Brogan, 1994; Reddi, 2003). A limiting value of 4 may be acceptable for

5 loosely packed filters, and a slightly higher value may be used for dense filters that have a

6 clear division point between the coarser and finer fractions. A less conservative boundary of 5

7 was proposed for $r_{f}$ by Sherard (1979), and the criterion of Kezdi (1979) was subsequently

8 validated by others as an acceptable guide (Fannin and Moffat, 2006).

9

10 USACE (1953) experimentally evaluated the role of soil composition in controlling the

11 inherent (internal) instability potential. Kenney and Lau (1985) reassessed this test procedure

12 and examined the role of particle gradation in greater depth. Based on the experimental results,

13 the particle size distribution (PSD) was related to the constriction size distribution (CSD),

14 whereby the $(H / F)_{\min }$ ratio was considered to represent the potential of suffusion. $H$ is the

15 percentile fraction by mass between particle size $d$ and $4 d$, with the assumption that a particle

16 of size $d$ can pass through the constrictions produced by the particle sizes equal to or greater

17 than $4 d . F$ represents an arbitrarily chosen point on the PSD curve that does not exceed $30 \%$

18 finer for uniformly graded and $20 \%$ finer for well graded granular soils, corresponding to a

19 particle size $d$. The absence of intermediate sizes was represented by $(H / F)_{\min }<1$.

20

21 The primary fabric forms a variety of constriction sizes, depending on its PSD and relative

22 density $\left(R_{d}\right)$ (Locke et al. 2001; Indraratna et al. 2007). The fines eroded through one

23 constriction may be captured by another, promoting self-filtration. The amount of finer fraction

24 helps to control the potential for internal instability, for which various estimates may be found

25 in literature. For example, Kenney and Lau (1985) estimated the amount of maximum fines that 
1 may be considered erodible for uniform and well graded granular soils. In gap-graded soils, the

2 fine limit of the gap in gradation curves may conveniently differentiate between coarser and

3 finer fractions (Xiao and Shwiyhat, 2012). More recently, Indraratna et al. (2011) extended the

4 constriction based retention criterion of Raut and Indraratna (2008) to evaluate the potential of

5 suffusion of granular soils. The theory of Aberg (1992) was adopted to compute the void ratios

6 of granular soils at known or assumed compaction levels. These methods claimed partial

7 success after a large number of samples from the published literature were plotted in the

8 transition zones, and for which hydraulic retests were consequently recommended. The

9 validation with the published literature suffered various limitations and simplifications, because,

10 inadequate data to compute CSD prevented objective comparisons, so no clear boundaries could

11 be drawn between the stable and unstable samples.

13 The objective of the current study was to evaluate and improve upon the available geometrical 14 methods for assessing potential internally unstable soils through additional specific data by the 15 authors. Hydraulic tests on fine sand as well as sand-gravel mixtures with a variation of the 16 uniformity coefficient $\left(C_{u}=1.2-40\right)$, compacted at different relative densities (5-95\%) were 17 conducted. Observations from these experiments enabled two distinct constriction based 18 methods (Kenney and Lau, 1985; Indraratna et al. 2007) to be combined together to accurately 19 establish the boundary between internally stable and unstable gradations. Unlike most of the 20 past geometrical criteria, the proposed criterion is sensitive to both particle size distribution 21 (PSD) and the relative density $\left(R_{d}\right)$ of the filter medium. 


\section{Experimental Program}

\section{Test Gradations and Geometrical Assessments}

3

4 A total of 20 hydraulic tests were performed on six granular soil samples having

$5 C_{u}=1.2,5,10,20,23$, and 40 , and they are identified by $C-1$ (uniform medium sand), $C-5$ and

$6 \quad C-10$ (well-graded gravelly sand), $C-20, C-23$, and $C-40$ (well-graded sandy gravel), as shown

7 in Fig. 1. All samples were prepared by compacting at the predetermined relative densities of

$8 R_{d}=5,50$ and $95 \%$ except $C-20$ and $C-23$ samples. The $C-20$ corresponds to the Fuller curve

9 (i.e. stability boundary proposed by Kenney and Lau, 1985), which was compacted at $R_{d}=5$,

1050,70 , and $95 \%$ and the marginally stable $C-23$ sample was compacted at $R_{d}=5,30,60$, and

$1195 \%$. This approach enables one to examine whether or not the internal instability potential

12 would be affected by the change in $R_{d}$. In this paper, a test sample is identified by C- $a$-R $b$,

13 where $a$, and $b$ respectively represent magnitude of $C_{u}$ and target $R_{d}$ values. Figs. 2(a) and 2(b)

14 presents selected geometrical assessments of the potential of internal instability through some

15 of the well-known methods. Kenney and Lau (1985)'s method assessed $C-1, C-5, C-10, C-20$

16 and $C-23$ as internally stable, but $C-40$ as internally unstable (Fig. 2(c)). Kezdi (1979)'s

17 method assessed $C-1, C-5, C-10$, and $C-20$ as internally stable, and $C-23$ and $C-40$ as unstable.

18 However, the application of Sherard (1979)'s approach classifies all the current test gradations

19 as internally stable except $C$-23 (Fig. 2(b)). In the following sections of this paper, all these

20 specimens have been re-analysed experimentally.

\section{Test Setup and Procedure}

The test apparatus consisted of a specially manufactured smooth perspex_filtration cell with an internal diameter of $150 \mathrm{~mm}$ and a height of $250 \mathrm{~mm}$, to accommodate $200 \mathrm{~mm}$ long 
1 specimens, as shown in Fig. 3. The cell dimensions were sufficiently large compared to

2 largest particle size $\left(D_{100}\right)$ of the tested soil. For instance, the ratio $R\left(D_{C E L L} / D_{100}\right)$ for most

3 samples was greater than 9. In the past, most filtration testing had been conducted using

4 equipment with $R$ ranging from 4 to 7, reporting it sufficient to avoid the effects of boundary

5 wall friction i.e. preferential flow paths and excessive frictional resistance to the erosion of

6 fines, and reported consistent results (e.g. see Fannin and Moffat, 2006; Moffat et al., 2011;

7 Zou et al., 2013 etc). The sample was placed inside the cell over a wire mesh with a nominal

8 opening of 80 microns, and then compacted to the target height. An electro-pneumatic pump

9 was connected to the bottom of the cell to allow inflow at a predetermined pressure. A

10 pressure transducer was attached to the outflow pipe to measure the differential head causing

11 upward flow through the specimen. An outlet valve also helped to control the differential

12 head. The circulation of effluent to sampling chambers facilitated the collection of eroded

13 fines for post-test forensic analysis.

15 The soil samples were mixed beforehand and then compacted in five distinct but uniform layers within the hydraulic test cell. The limiting void ratio of each sample was determined

17 using the standard test procedures (ASTM D-4253 and ASTM D-4254). The target relative densities were then attained by controlling the dry soil mass, volume, and moisture content. The sample preparation method of Skempton and Brogan (1994) was found to be effective in obtaining loose specimens $\left(R_{d} \approx 5 \%\right)$, which required placing the soil in discrete layers and compacting it either by hand or allowing compaction under self-weight. Samples at intermediate compaction levels $\left(R_{d} \approx 30,50,60\right.$ and $\left.70 \%\right)$ were placed in discrete layers and then compacted by a steel rod (300 $\mathrm{mm}$ long and $20 \mathrm{~mm}$ diameter and weighing $0.75 \mathrm{~kg}$ ), while a very dense specimen $\left(R_{d} \approx 95 \%\right)$ had to be prepared by compacting with a standard compaction hammer. For current study, adopting the procedures outlined by Das (2008) and 
1 Scott et al. (2012), the imparted compaction energies $\left(E_{c}\right)$ were estimated to be $564,364,313$,

2263,157 and $26 \mathrm{~kJ} / \mathrm{m}^{3}$ for preparing specimens with $R_{d} \approx 95 \%, 70,60,50,30$ and 5, 3 respectively. The uniformity of test specimens was assessed by preparing additional 4 specimens using similar technique and by measuring (a) the overall $\gamma_{d}$-values for each 5 specimen and (b) for a given specimen, the $\gamma_{d}$-values of small specimens cored within each

6 layer. The dry density for each layer and overall specimen was found similar (deviation $<$ 7 6\%), indicating uniform compaction across the specimen depth, hence preventing any layering 8 effects. With regard to size gradation of samples, the uniformity was assessed through the 9 comparison of pre- and post-test sieve analysis, and the summary is provided in Table 1 . The erosion of the material is partially represented by the loss of finer fractions that would increase the post-test uniformity coefficient $\left(C_{u}=D_{60} / D_{10}\right)$ compared to that of the initial particle size distribution. For example, in sample C-23-R5 the $C_{u}$-value decreased from 23 to 18.2 due to erosion of finer material at the $D_{10}$ level.

The test procedure involved subjecting the saturated specimen to the upward flow of water at pre-determined pressure levels. For geometrically assessed stable specimens, the increments 17 of $i$ were 0.04 to 0.05 and for unstable specimens these increments were 0.02 to 0.025 , as incorporated in Fig. 4. The above increments of $i$ were kept small enough such that the accurate value of $i_{c r, \exp }$ could be determined at the onset of sample instability. The duration of running the test at a certain value of $i$ lasted up to 25 to 30 minutes beyond which steady state flow was observed. The next increment of $i$ was then applied for the subsequent stage. The wire mesh did not allow any finer fractions to escape while the specimen was being saturated; this was completed by filling the cell with de-aired water and leaving it for a minimum of 24

24 hours, under a relatively small constant head of $50 \mathrm{~mm}$ applied at the top of specimen (i.e. 
1 because, during preliminary trials some loosely compacted specimens indicated slight internal

2 disturbance under upward flow. The flow velocity was measured repeatedly during the test by

3 collecting a specific volume of effluent in a graduated cylinder over a given time period. The

4 permeability of current gradations could be deduced from the slope of the flow relationships

5 plotted in Fig. 4, and by assuming linear Darcy's law. In this study, the onset of 'failure' was

6 characterised by a marked rise in the effluent flow velocity (i.e. sharp increase in slope of the

7 flow curves shown in Fig. 4) and an increased effluent turbidity significantly greater than 60

8 NTU. At such onset of failure, the corresponding $i_{\text {exp }}$ values were assumed to be $i_{c r, \exp }$.

9 These values of $i_{c r, \exp }$ would also corroborate with the visual instability tell-tale signs of specimen such as heave or piping, sudden mass washout etc. After testing, specimens were

11 retrieved from five distinct layers for sieve analysis, and the resulting data was then plotted to

12 compare with the original soil gradations. An unaltered central layer PSD could be considered 13 as a rationale to distinguish between stable and unstable gradations.

\section{Results and Discussions}

17 Table 1 presents some of the physical properties of test samples (i.e. uniformity coefficient, 18 relative density, saturated unit weight, and Terzaghi's theoretical critical hydraulic gradient,

$\left.19 i_{c r, t h}\right)$. It also tabulates the results of laboratory tests conducted in this study (e.g. experimental 20 (observed) critical hydraulic gradient $i_{c r, \exp }$, eroded fines content, and post-test settlement 21 etc.). As discussed in the following sections, the experimental gradients of all the soil samples 22 tested were found to be proportional to the degree of compaction, irrespective of whether the sample was stable or unstable. 


\section{Hydraulic Test Results}

2

3 The results of the hydraulic tests are presented in Fig. 4. The flow curves for the stable soil 4 samples $(C-5, C-10, C-20-R 70, C-20-R 95, C-23-R 30, C-23-R 60$, and $C-23-R 95)$ abided by

5 Darcy's law to an appreciable extent such that, experimental hydraulic gradients $\left(i_{\text {exp }}\right)$ as high

6 as 0.40 plotted linearly against the flow velocities. However, the application of $i_{\text {exp }}$ ranging 7 from 0.40 to 0.60 increased in steepness such that some slight local rearrangement of fines 8 occurred during the tests. This is consistent with the experimental observations of Skempton 9 and Brogan (1994), where small variations could be attributed to higher compaction. A further 10 increase in $i_{\text {exp }}$ (from 0.65 to 0.80 ) in almost every stable sample induced higher flow 11 velocities and slight local rearrangement of fines, particularly in $C-10-R 5, C-20-R 70, C-20$ $12 R 95, C-23-R 30, C-23-R 60$, and $C-23-R 95$. The gradients exceeding 0.80 generated local 13 tributaries that joined together to result in heave in almost every stable sample, when $i_{\text {exp }}$ 14 approached unity. However, the internally unstable samples $(C-40, C-20-R 5, C-20-R 50$, and $C$ 23-R5) suffered from excessive washout of fines at $i_{\text {exp }}(0.28$ to 0.62$)$ significantly smaller than the theoretical critical hydraulic gradients $\left(i_{c r, t h}\right)$, as summarized in Table 1.

During the post-test examination, all the tested samples were carefully retrieved in five equivalent (identically compacted) layers, for which the PSDs of the central layer-3 were then determined. As expected, a stable gradation resulted in insignificant PSD variation of its central layer, particularly in samples $C-1, C-5$ and $C-10$ which experienced heave without any excessive washout at the onset, while their measured critical hydraulic gradients $\left(i_{c r, \text { exp }}\right)$ were observed to be close to unity (Figs. 4(a), 4(b), and 4(f)). These samples were evaluated as internally stable by a number of past geometrical methods (Kezdi, 1979; Sherard, 1979; Kenney and Lau, 1985). Sample $C-23-R 30\left(R_{d} \geq 30 \%\right)$ and more densely compacted $C$-20- 
$1 R 70\left(R_{d} \geq 70 \%\right)$ samples also proved stable, because, heave only occurred at values of $i_{c r, \exp }$

2 close to $i_{c r, t h}$ (Terzaghi, 1939). For instance, $i_{\text {exp }} \approx 0.85$ initiated heave in $C-20-R 70$, but no

3 significant erosion of its finer fraction was observed until $i_{\text {exp }}$ exceeded 0.90. At this stage,

4 large visible channels joined together to form a composite failure mode (heave + piping) as

$5 i_{c r, \text { exp }}$ approached unity. More importantly, the erosion of its finer fraction was contained

6 significantly as the degree of compaction of $C$-20 (Fuller curve) increased. This proved that the

7 Fuller curve was only partially stable at higher relative densities $\left(R_{d} \geq 70 \%\right)$, which is in

8 agreement with a similar gradation reported by Kenney and Lau (1985). Similarly, the

9 increasing level of compaction $\left(R_{d}=5\right.$ to $\left.95 \%\right)$ substantially reduced the amount of eroded

10 fines from $C-23$ (marginally stable sample with $(H / F)_{\min }=1.06$ ). The above results clearly

11 confirm the role of relative density $\left(R_{d}\right)$ on the internal stability of these samples in addition to

12 the influence of PSD alone.

14 An attribute similar to the stable gradations was initially shown by the internally unstable samples (C-20-R5, $C-20-R 50, C-23-R 5$, and $C 40)$, when subjected to increasing $i_{\text {exp }}$ ranging from 0 to 0.1, as shown in Fig. 4(c), 4(d), and 4(e). Initially, the flow velocity kept increasing

17 linearly with the applied $i_{\text {exp }}$, however, Darcy's law ceased to define the correlation between increasing $i_{\text {exp }}$ and flow velocities after the $i_{\text {exp }}$ values barely exceeded 0.1 . The slope of the curve increased more steeply than a stable specimen at the onset of failure, and the post-test sieve analyses revealed that none of the layers resembled the original PSD. Eroded fines contained particles up to $1.18 \mathrm{~mm}$ in size, and the onset of failure was characterized by a substantial washout in almost every test performed on internally unstable samples. The values 23 of $i_{c r, \exp }(0.28-0.62)$ governing the onset of failure were incomparably smaller than $i_{c r, t h}$ 24 (generally close to 1.0), which also lend support to the correct evaluation of internally unstable gradations ( $C-20-R 5, C-20-R 50, C-23-R 5$, and $C 40)$, experiencing excessive washout at failure. 
1 An increasing relative density somehow decreased the quantity of erodible fines, although C-

240 proved internally unstable at all values of $R_{d}$.

3

4 In lieu of measuring the mass loss with time, the effluent turbidity (measured in NTU) could be

5 monitored as an effective measure of soil erosion (Indraratna et al., 1996; Indraratna and

6 Radampola, 2002). In this study, at the onset $i_{c r, \text { exp }}$ initiating significant erosion, the effluent

7 turbidity increased significantly (NTU» 60). However, with the exception of C-40 that

8 continued to erode, for all other specimens the erosion levelled off with time after about 30

9 minutes of testing. The corresponding effluent turbidity became clearer once again (i.e. NTU <

10 25), and remained relatively constant thereafter. Subsequent erosion of loosely compacted

11 internally unstable specimens (e.g. C-20-R5 and C-23-R5) occurred upon further increase in

12 the hydraulic pressure (see Fig. 4). The eroded fines were transported by the upward flow of

13 water and there was no indication of any significant sedimentation or caking on top of the

14 specimens. Therefore, one may assume that the eroded particles were sufficiently fine enough

15 to be carried by the outflow velocity.

\section{Effect of Level of Compaction}

19 Fig. 5(a) presents relationships between relative density $\left(R_{d}\right)$ and the critical hydraulic gradients $\left(i_{c r, \text { exp }}\right)$ for all test samples. In this paper, solid symbols are consistently used to plot

21 an internally stable samples and hollow symbols for unstable samples. The magnitude of

$22 i_{c r, \exp }$ proportionally increased with the level of compaction in almost every test sample. In

23 close agreement with the theory of Terzaghi (1939), the sample $C$ - 1 (uniformly-graded fine

24 sand) experienced heave at $i_{c r, \exp } \geq i_{c r, t h}$, independent of its $R_{d}$. However, the magnitude of $25 i_{c r, \exp }$ substantially increased with the increasing level of compaction and still remained higher 
1 than $i_{c r, t h}$. For instance, at $R_{d} \approx 5 \%$ the value of $i_{c r, \exp }$ was found to be 1.07 with the

2 corresponding $i_{c r, t h}$ value of 0.97 and at $R_{d} \approx 95 \%$, the values of $i_{c r, \exp }$ and $i_{c r, t h}$ were

3 determined as 1.29 and 1.18, respectively. These variations may be attributed to the increased

4 inter-particle contacts due to increased values of $R_{d}$. Similarly, samples $C-5$ and $C$-10 (well-

5 graded sandy gravel mixtures) showed close agreements with Terzaghi's theory, however, the

6 increasing level of compaction somehow improved the magnitude of $i_{c r, \exp }$ (e.g. 1.0 at $R_{d} \approx$

$75 \%$ to 1.10 at $R_{d} \approx 95 \%$ for $C-1$ ). Samples $C-20$ and $C-23$ experienced significant increases in

8 the magnitude of their respective $i_{c r, \text { exp }}$ values with increasing $R_{d}$, which then started to

9 approach $i_{c r, t h}$. Samples $C-40$ (broadly-graded sandy gravels) experienced some increase in

10 the magnitude of $i_{c r, \exp }$ from 0.28 to 0.40 with the increasing magnitude of $R_{d}$ (from 5 to

$1195 \%$ ), however, they did not manage to reach even $50 \%$ of $i_{c r, t h}$ at the loosest state of

12 compaction $\left(R_{d} \approx 5 \%\right)$. Fig. 5(b) presents the relationships between relative density and the

13 normalized hydraulic gradient, $\Delta i_{c r}\left(=i_{c r, \exp } / i_{c r, t h}\right)$. For internally stable samples $(C-1, C-5$

14 and $C$-10), the $\Delta i_{c r}$ values did not vary substantially regardless of the compaction level.

15 Similarly, the internally unstable samples (all C-40 samples) failing at $i_{c r, \exp }(0.28$ to 0.40 )

$16 \ll i_{c r, t h}$ (approximately unity), exhibited insignificant increase in $\Delta i_{c r}$ values with the

17 increasing level of compaction. This implies that the increasing $R_{d}$ cannot reduce the

18 controlling constriction size sufficiently enough to retain the representative particle size of the

19 finer fraction, thus no local self-filtration is encountered.

21 The relationship between relative density $\left(R_{d}\right)$ and normalized critical hydraulic gradient $\left(\Delta i_{c r}\right)$

22 values for $C-20\left((H / F)_{\min }=1.0\right)$, showed a marked distinction in behaviour from all other test

23 samples. At the loosest state of compaction, $i_{c r, \exp }$ was as small as 0.45 , which is in close

24 agreement with a loosely compacted gradation of Skempton and Brogan (1994), i.e. (H/ 
$1 F)_{\min }=0.98$ failing at $i_{c r, \exp }=0.34$. Increasing compaction level affected the controlling

2 constriction size of $C$-20 as the magnitude of $i_{c r, \exp }$ kept increasing significantly with the

3 relative density, transforming it from being internally unstable to internally stable at $R_{d} \geq 70 \%$.

4 For example, the unstable sample $C-20-R 50$ failed at $\Delta i_{c r} \approx 0.5$, which then experienced

5 almost a twofold increase in $\Delta i_{c r}(\approx 0.9)$ to be transformed from internally unstable to stable,

6 when the magnitude of $R_{d}$ was doubled $(C-20-R 95)$. The post-test sieve analysis results

7 discussed later in this paper also confirm that the central layers of $C-20$ samples compacted at

$8 R_{d} \geq 70 \%$ were unchanged, supporting the argument that the Fuller curve is only partially

9 stable at higher compaction levels $\left(R_{d} \geq 70 \%\right)$. Similar attributes were shown by the marginally

10 stable sample $C$-23, whereby, the increasing level of compaction from $R_{d} \approx 5 \%$ to $30 \%$

11 substantially improved the magnitude of $\Delta i_{c r}$ from 0.63 to 0.81 . Further increase in $R_{d}$ (30-

$1295 \%)$ continued to improve $\Delta i_{c r}(0.81-0.93)$ in $C-23$ samples, which confirms that the level of

13 compaction is indeed a key factor controlling the internal stability of granular soils.

15 The stable specimens generally abided by the piping theory (Terzaghi, 1939), whereby the

16 values of normalized hydraulic gradient $\left(\Delta i_{c r}\right)$ remained closer to unity for the majority of

17 stable samples. Small variations are acceptable, because, the classical piping theory

18 (Terzaghi, 1939) was originally proposed for uniform sands, while the majority of current

19 samples are well-graded sand-gravel mixtures. Images taken at the onset of failure for some of

20 the test samples are presented in Fig. 6, and they show that the stable samples $(C-5, C-10, C$ -

21 20-R70, C-20-R95, C-23-R30, C-23-R60, and C-23-R95) experienced heave at $i_{c r, \exp }$

22 approaching $i_{c r, t h}$ (approximately 1.0), while the unstable samples (C-20-R5, $C$-20-R50, $C$-23-

23 R5. and $C$-40) suffered from excessive washout even at very small hydraulic gradients

$\left(i_{c r, \exp } \approx 0.28\right.$ to 0.62$)$. 


\section{Erodible Fines and Post-tests Settlements}

2

3 The relationship between the percentile eroded fines and the magnitude of post-test settlement

4 of the tested samples was also examined. The eroded fines were recovered, dried and weighed

5 to obtain the percentile loss of fines $(f)$ from each test sample. A check of the difference

6 between pre and post-test intact sample mass in the permeameter confirmed the successful

7 capture of eroded fines. Fig. 7 shows the relationship between eroded fines and the percentage

8 of reduction in height $s(=\Delta h / h)$, where $h$ represents the original sample height. The

9 reduction in height $(\Delta h)$ was calculated as the average of minimum 10 measurements taken

10 along the height of a tested sample, after allowing post-test subsidence prior to being subjected

11 to sieve analysis. Not surprisingly, it was the loose $C-10-R 5$ sample that indicated slightly

12 higher net settlement (i.e. $2-2.5 \mathrm{~mm}$ ) compared to the rest of stable samples. However, the total

13 reduction in height never exceeded $2 \%$ with the increasing compaction level, irrespective of

14 whether a sample was stable or unstable, even if the loss of fines was as high as $16 \%$.

16 Three distinct zones are defined in Fig. 7, wherein, the stable and unstable samples plot in

17 zone-I (heave zone) and zone-III (washout zone), respectively, with just two samples ( $C$-20-

$18 R 70$ and $C$-23-R30) falling in the transition zone-II (heave-piping zone). Sample $C$-20 could be

19 transformed from being internally unstable to stable by enabling more than $4 \%$ reduction in

20 erodible fines due to increased compaction $\left(R_{d}=70 \%\right)$, but the total reduction in percentile

21 settlement did not even reach $1 \%$. It follows that while the erodible fines were free to displace

22 with the seepage flow, this amount of washout bears no direct relationship to the reduction in

23 specimen height or influence the primary fabric of the soil that governs volume change and

24 stress transfer. Further increase in $R_{d}$ from $70 \%$ to $95 \%(C-20-R 95)$ moved $C$-20 into the stable

25 heave zone-I. This clearly suggests that the extent of washout can be minimised by reducing 
1 the constriction sizes by increased $R_{d}$. For loose soils, the CSD curve is broader and the

2 controlling constriction size may be too large to capture the eroding particles, but the increased

3 level of compaction narrows the CSD width, and the controlling constriction $\left(D_{c 35}\right)$ may then

4 fulfil the criterion set by Indraratna et al, (2007) for effective filters to initiate self-filtration.

5 Fig. 8 presents the relationship between relative density and percentile eroded fines. The 6 general effect of increasing $R_{d}$ is reflected by an overall reduction in the amount of eroded

7 fines of all stable samples shown by solid symbols (i.e. $C-5, C-10, C-20-R 70, C-20-R 95, C-23-$

8 R30, $C-23-R 60$, and $C-23-R 95$ ). On the other hand, the internally unstable samples (hollow

9 symbols in Fig. 8) exhibited excessive washout of fines (C-20-R5, $C-20-R 50, C-40)$. However,

10 in most samples, the extent of washout reduced significantly with the increasing relative

11 density. For example, with the increase in $R_{d}$ from 5 to $95 \%$, the eroded fines in $C$-20 and $C$ -

1223 reduced from 7.64 to $1.71 \%$ and from 6.42 to $0.96 \%$ respectively. This further reinforces

13 the argument that compaction promotes self-filtration and more sustainable load transfer within

14 the soil fabric, as also concluded by Trani and Indraratna (2010), who proposed an optimum

15 constriction size retention criterion for sub-ballast filtration under cyclic loading.

\section{Estimation of Eroded Fines from PSD}

A method of estimating the percentage of eroded fines from a given PSD is depicted in Fig. 9. It involves the discretization of both curves (i.e. original as well as that subjected to erosion) from an arbitrary division point corresponding to $(H / F)_{\min }$ on the original gradation. The corresponding mean percentage passing by mass $\left(f_{a v g, i}\right.$ and ${f^{\prime}}^{\prime}{ }_{a v g, i})$ can then be calculated by;

$$
f_{c}=\frac{1}{\Delta d} \sum_{i=1}^{i=n}\left(f_{\text {avg }, i} \cdot d_{i}-f^{\prime}{ }_{a v g, i} \cdot d_{i}^{\prime}\right)
$$

$$
\Delta d=\sum_{i=1}^{i=n} d_{i}
$$


3 In the above expressions, $f_{c}(\%)$ is the total amount of eroded fraction from central layer

4 (layer-3 recovered from the middle of a tested sample), $d_{i}$ and $d^{\prime}{ }_{i}(\mathrm{~mm})$ are width of the slices,

$5 \Delta d(\mathrm{~mm})$ is the total width of the eroded portion of original curve, $f_{1 i}, f_{2 i}, f^{\prime}{ }_{1 i}$, and $f^{\prime}{ }_{2 i}$ are

6 the limiting \% finer by mass for the slices under consideration, and $f_{a v g, i}$ and $f^{\prime}$ avg,i define

7 the arithmetic mean of limiting $\%$ finer by mass for the $i^{\text {th }}$ and $i^{\prime \text { th }}$ slices in Fig. 9,

8 respectively. An unaltered internally stable central layer will have a PSD that almost coincides

9 with that of the original filter. The soil samples reaching $i_{c r, \exp } \approx i_{c r, t h}$ (generally close to 10 1.0), experiencing loss of fines less than $2.5 \%$ from the central layer are also internally stable

11 (i.e. relatively unchanged uniformity coefficient). For current test results, a summary of the 12 percentage of eroded fines from the central layer estimated using the proposed method (Eq. 1), 13 and a comparison of the pre- and post-test uniformity coefficients are, presented in Table. 1.

\section{A New Combined PSD and CSD (CP-CSD) Method to Assess Internal Instability}

17 In order to evaluate the potential of internal instability, the granular filter itself can be idealized into a base soil-filter system depending on its gradation (PSD curve) and the Relative Density, $R_{d}$. Naturally, the choice of demarcation on the PSD curve requires caution, and the following approach is proposed: adopting the method of Kenny and Lau (1985).

(ii) The resulting coarser fraction may now be assumed as the filter component, while the finer fraction is considered as the base soil. 
1 (iii) To assess the potential of internal instability, one may now plot the PSD of the identified base soil fraction by the surface area (SA) technique, and the CSD of the filter component for a given relative density $\left(R_{d}\right)$ as shown in Fig. 10.

4 (iv) The final step is to apply the optimum constriction size based criterion proposed by

11 For the above combined approach (hereafter termed as CP-CSD method), Fig. 11 presents the 12 plot between the controlling constriction sizes of the coarser fraction $\left(D_{c 35}^{c}\right)$ and the 13 representative particle sizes of the finer fraction by surface area $\left(d_{85, S A}^{f}\right)$. To plot the CSD of 14 the coarser half, the use of $R_{d}$ of the original gradation is recommended, because, the fines are 15 physically present within the granular assembly during the entire filtration process. A distinct 16 boundary between internally stable and unstable samples is evident. A comparison of 17 predictions from various geometrical criteria and the proposed CP-CSD method is presented in 18 Table 2. The available geometrical methods could only partially succeed in delineating the 19 stable samples from unstable ones to be consistent with the experimental observations. For 20 instance, the methods of Kezdi (1979), Sherard (1979), and Kenney and Lau (1985) give five 21 (2 unsafe and 3 conservative), eight (5 unsafe and 3 conservative), and three (unsafe) 22 inconsistent predictions, respectively. However, the CP-CSD method successfully 23 distinguished between the stable and unstable samples. 


\section{Validation of the Proposed CP-CSD Method}

2

3 A data set of 92 test samples from the published literature and the experimental results of 4 current study have been used to validate the proposed geometrical method, and Table 3 5 summarises the test series numbers, specimen identities (ID), and the corresponding $C_{u}$ and $R_{d}$ 6 values, and the $(H / F)_{\min }$ ratios. Additionally, the division points $P_{d}$, the corresponding $7\left(D_{c 35}^{c} / d_{85, S A}^{f}\right)$ values, the CP-CSD evaluations and the experimental results of all the samples 8 are tabulated. The data set includes 14 test results by Kenney and Lau (1985), 4 from 9 Skempton and Brogan (1994), 13 each from Honjo et al. (1996) and Sherard et al. (1984a), 6 10 from Nguyen et al. (2013), 6 from Indraratna et al. (2012), 5 from Indraratna et al. (2007), 3

11 from Indraratna et al. (1996), 2 from Indraratna and Vafai (1997), 2 from Locke et al. (2001), 4

12 from Lafleur et al. (1989) plus 20 additional laboratory data sets from this study. These test 13 results were specifically selected because either the $R_{d}$ of each specimen was known or it could be assumed reasonably well based on the preparation method. For example, Kenney and Lau (1985) prepared their test samples at a high compaction level, hence $R_{d} \approx 90 \%$ could be assumed, and in contrast, the sample preparation of Skempton and Brogan (1994) resembled the loosest state (i.e. $R_{d} \approx 5 \%$ ). Overall data for validation included 13 gap-graded and 79 specimens with variation of $C_{u}$ ranging from 1.2 to 50 .

20 For all the 92 samples, Fig. 12(a) presents the assessments based on the method of Kenney and 21 Lau (1985). The test series numbers indicated in Table 3 are used to mark the inconsistent 22 predictions plotted on Fig. 12, such that the test series numbers inside circles and rectangles are used to represent the conservative (safe) and unsafe predictions, respectively. There are a total

24 of 8 inconsistent predictions including 6 unsafe and 2 conservative assessments. As presented 25 earlier in Table 3, the unsafe predictions include one each from Kenney and Lau (1985) (Test 
1 series No. 1), Skempton and Brogan (1994) (Test series No.32), Honjo et al. (1996) (Test

2 series No. 56), and 3 gradations of the current study (Test series Nos. 82, 83, and 86). The

3 conservatively assessed samples include one each from Kenney and Lau (1985) (Test series

4 No. 2) and Honjo et al. (1996) (Test series No. 49). The overall success rate is close to 90\%,

5 which is still acceptable for all practical purposes. However, the success rate improves further,

6 when the proposed CP-CSD method is used to delineate the potential of internal instability.

7 The results of internal instability assessments from the CP-CSD method for the same set of 92

8 data points are presented in Fig. 12(b). Apart from 1 incorrect predictions (Test series No. 1),

9 all other 91 samples are correctly assessed using the proposed CP-CSD method (i.e. $\approx 99 \%$

10 success). In Table 3, sample A (Test series No.1: Fuller curve) is geometrically assessed as a

11 stable filter by all methods, while it is deemed unstable when tested in the laboratory under

12 extreme hydraulic conditions (i.e. hydrodynamic number, $R^{\prime}=29$ corresponding to $i_{\text {exp }}>1$ )

13 accompanying significant vibrations (Kenney and Lau, 1985). A probable explanation for this

14 discrepancy is that the Fuller curve is only partially stable at a higher compaction level $15\left(R_{d} \geq 70 \%\right)$ and the stability largely depends upon the test conditions, whereby the 16 constrictions (hence CP-CSD method) can be adversely affected by excessive vibrations (Xiao 17 et al. 2006).

Based on the above analysis, it was found that the proposed CP-CSD method could assess the potential of internal instability with almost perfect accuracy for both the current and published

21 test data. It evaluates the potential of internal instability on the basis of both PSD and $R_{d}$ (hence 22 capturing the CSD), while other geometrical methods (e.g. Kenney and Lau, 1985) do not

23 directly capture the role of $R_{d}$ or CSD. The CP-CSD method enhances the rigor of assessing 24 the internal instability potential, thereby contributing towards an increased level of confidence 25 in practical design of granular filters. 


\section{Conclusions}

2

3 In this study, laboratory hydraulic tests were conducted to assess and interpret the internal

4 instability of six granular soil samples of varying relative density, in conjunction with a wide

5 array of experimental results taken from past studies. A technique combining the particle size

6 distribution (PSD) and the associated relative density $\left(R_{d}\right)$, thus the role of the constriction size

7 distribution (CSD) of the granular mass, was developed to demarcate the internally stable

8 samples from the unstable counterparts as accurately as possible.

9

10 Apart from the PSD of a given granular sample, its degree of compaction also influences the

11 amount of fines eroded under a critical hydraulic gradient. Depending upon the compacted

12 relative density $\left(R_{d}\right)$, marginally unstable (borderline) samples can transform into stable ones

13 and the vice versa. For instance, specimens $C-20$ and $C-23$ experienced more than $4 \%$

14 reduction in eroded fines and transformed into being internally stable, when their relative

15 densities were increased from $6.1 \%$ to $71.1 \%$ and from $7.35 \%$ to $32.05 \%$, respectively.

16 Therefore, in order to accurately predict the internal stability of a granular mass, it is

17 imperative to consider both its PSD and $R_{d}$ in tandem, thus elucidating the prominent role of

18 the constrictions too, and not just the particle sizes as considered in conventional geometrical

19 approaches.

21 The proposed approach (CP-CSD) coupling two distinct PSD and CSD based methods

22 capturing the relative density requires demarcating the PSD of the granular mass at a specific

23 division point. Inspired by Kenney and Lau (1985) approach, this division point is defined by

$24(H / F)_{\min }$ ratio up to $30 \%$ finer by mass, thereby establishing an idealized base soil-filter

25 system within its own PSD. It is then subjected to the optimized CSD criterion proposed by 
1 Indraratna et al., (2007) to evaluate the effectiveness of the coarse fraction above the division

2 point (i.e. filter component) in retaining the separated finer fraction (i.e. base soil). In contrast

3 to other geometrical methods, the consistency of this CP-CSD approach in relation to the

4 reported experimental results is remarkable. For instance, out of the 92 data points considered

5 here, the application of the original approach of Kenney and Lau (1985) gave 8 inconsistent

6 predictions, compared to just one inaccurate assessment by the proposed CP-CSD method (i.e.

$7 \approx 99 \%$ success). This single discrepancy could be attributed to excessive vibration imparted

8 during hydraulic testing.

9

10 Given that the proposed CP-CSD technique incorporates the significance of both particle sizes

11 and the sensitivity to the degree of compaction (hence the role of constriction sizes), it is more

12 reliable and realistic to be used in practice compared to the past geometrical methods.

13 Nevertheless, considering the nature of test samples considered herein, caution must still be

14 exercised when the proposed CP-CSD technique for granular soils is applied to those of

15 significantly different properties, such as predominantly gap-graded materials and cohesive 16 soils. 


\section{Acknowledgements}

2

3 Financial support received by second author for current work in the form of Faculty

4 Development Program (FDP) as well as International Postgraduate Tuition Award (IPTA)

5 scholarships from University of Engineering and Technology Lahore (Pakistan) and University

6 of Wollongong (Australia), respectively, is gratefully acknowledged.

7

8

9

10

11

12

13

14

15

16

17

18

19

20

21

22

23

24

25 


\section{Notation}

2

3 Following symbols are used in this paper:

4

$5 \quad C_{u}=$ coefficient of uniformity;

$6 \mathrm{CSD}, \mathrm{PSD}=$ constriction size and particle size distributions;

$7 \mathrm{CP}-\mathrm{CSD}=$ combined particle and constriction size distribution method;

$8 d, 4 d=$ arbitrary particle sizes on PSD by mass $(\mathrm{mm})$;

$9 \mathrm{~d}_{85, \mathrm{SA}}^{\mathrm{f}}=$ representative size for finer fraction from PSD by surface area technique $(\mathrm{mm})$;

$10 \mathrm{D}=$ particle size $(\mathrm{mm})$;

$11 \quad D_{C E L L}=$ cell diameter $(\mathrm{mm})$

$12 \quad D_{100}=$ largest particle size $(\mathrm{mm})$

$13 \mathrm{D}_{\mathrm{c} 35}^{\mathrm{c}}=$ controlling constriction for coarser fraction from CSD by surface area technique (mm);

$14 D_{15}^{c}=$ particle size corresponding to $15 \%$ finer for coarse fraction from PSD by mass (mm);

$15 D_{f}=$ arbitrary division point on PSD by mass ( $\left.\mathrm{mm}, \%\right)$;

$16 d_{85}^{f}=$ particle size corresponding to $85 \%$ finer for finer fraction on PSD by mass (mm);

$17 d_{i}, d^{\prime}{ }_{i}=$ width of the slices on original and eroded PSD curves, respectively (mm);

$18 F, H=$ percentage finer by mass corresponding to arbitrary size $d$ and $4 d$, respectively (\%);

$19 f=$ total percentile eroded fines from original PSD of overall sample (\%);

$20 f_{i}$ and $f^{\prime}{ }_{i}=$ limiting percentages finer for slices on respective original and eroded PSDs (\%);

$21 f_{\text {avg }, i}, f^{\prime}$ avg,i $=$ arithmetic mean of limiting percentages finer (\%);

$22 f_{c}=$ percentile eroded fines from central layer PSD of sample $(\%)$;

$23 h=$ original sample height $(\mathrm{mm})$;

$24(H / F)_{\min }=$ Kenney and Lau (1985)'s stability index;

25 ID $=$ test sample identification number; 
$1 i_{\text {exp }}, i_{c r, \exp }=$ applied hydraulic gradient and observed critical hydraulic gradient, respectively;

$2 i_{c r, t h}=$ Terzaghi (1939)'s theoretical critical hydraulic gradient;

$3 R=$ ratio between cell diameter and largest particle size;

$4 \quad R^{\prime}=$ hydrodynamic number;

$5 \quad R_{d}=$ relative density $(\%)$;

$6 r_{f}=$ ratio between the representative particle sizes of the coarser and the finer fraction;

$7 s=$ post-test settlement $(\%)$;

$8 \Delta d=$ total width of eroded portion on the original PSD layer $(\mathrm{mm})$;

$9 \Delta h=$ reduction in original sample height $(\mathrm{mm})$;

$10 \Delta i_{c r}=$ ratio of observed and corresponding theoretical critical hydraulic gradients;

$11 \gamma_{w}=$ unit weight of water $\left(\mathrm{kN} / \mathrm{m}^{3}\right)$; and

$12 \gamma_{s}=$ saturated unit weight of soil $\left(\mathrm{kN} / \mathrm{m}^{3}\right)$. 


\section{References}

2

3 Aberg, B. (1992). "Void ratio of noncohesive soils and similar materials," J. Geotech. Eng., 4 118(9), 1315-1333.

5 American Society for Testing and Materials (ASTM). (2006a) "Standard test methods for

6 maximum index density and unit weight of soils using a vibratory table," ASTM D4253-06,

7 West Conshohocken, Pa.

8 American Society for Testing and Materials (ASTM). (2006b) "Standard test methods for

9 minimum index density and unit weight of soils and calculation of relative density," ASTM

10 D4254-00, West Conshohocken, Pa.

11 Burenkova, V. V. (1993). "Assessment of suffusion in non-cohesive and graded soils." Filters

12 in geotechnical and hydraulic engineering, J. Brauns, M. Heibaum, and U. Schuler, eds.,

13 Bakema, Rotterdam, The Netherlands, 357-360.

14 Das, B. M. (2008). Advanced Soil Mechanics, Taylor \& Francis, London, UK.

15 Fannin, R., and Moffat, R. (2006). "Observations on internal stability of cohesionless soils." 16 Geotechnique, 56(7), 497-500.

17 Fourie, A. B., Copeland, A. M., and Barrett, A. J. (1994). "Optimization of the as-placed

18 properties of hydraulic backfill." J. South African Instt. Min. and Met., 94(8), 199-210.

19 Honjo, Y., Haque, M. A., and Tsai, K. A. (1996). "Self-filtration behaviour of broadly and 20 gap-graded cohesionless soils." Geofilters'96, J. Lafleur and A. Rollin, eds., Bitech 21 Publications, Montreal, 227-236.

22 Indraratna, B., and Vafai, F.(1997). "Analytical model for particle migration within base soil-

23 filter system.” J. Geotech. Geoenviron. Eng., 123(2), 100-109. 
1 Indraratna, B., Nguyen, V. T. and Rujikiatkamjorn, C. (2011). "Assessing the potential of

2 internal erosion and suffusion of granular soils.” J. Geotech. Geoenviron. Eng, 137(5). 550-

3554.

4 Indraratna, B., Nguyen, V. T., and Rujikiatkamjorn, C. (2012). "Hydraulic conductivity of

5 saturated granular soils determined using a constriction-based technique." Can. Geotech. J., $649,607-613$.

7 Indraratna, B., Raut, A. K., and Khabbaz, H. (2007). "Constriction-based retention criterion for 8 granular filter design.” J. Geotech. Geoenviron. Eng., 133(3), 266-276.

9 Indraratna, B. and Radampola, S. (2002). "Analysis of critical hydraulic gradient for particle 10 movement in filtration." J. Geotech. Geoenviron. Eng, 128(4), 347-350.

11 Indraratna, B., Vafai, F., and Dilema, E.(1996). "An experimental study of the filtration of a 12 lateritic clay slurry by sand filters." Proc. Instn Civ. Engrs. Geotec. Eng, 119(2), 75-83.

13 Kenney, T. C., and Lau, D. (1985). "Internal stability of granular filters." Can. Geotech. J., 22, $14 \quad 215-225$.

15 Kenney, T. C., and Lau, D. (1986). "Internal stability of granular filters: Reply." Can. Geotech. 16 J., 23, 420-423.

17 Kezdi, A. (1979). Soil physics, Elsevier Scientific, Amsterdam, The Netherlands.

18 Lafleur, J., Mlynarek, J., and Rollin, A. (1989). "Filtration of broadly graded cohesionless 19 soils." J. Geotech. Eng., 115(12), 1747-1768.

20 Li, M. and Fannin, R. J. (2008). “Comparison of two criteria for internal stability of granular 21 soil." Can. Geotech. J., 45, 1303-1309.

22 Locke, M., Indraratna, B., and Adikari, G. (2001). "Time-dependent particle transport through 23 granular filters.” J. Geotech. Geoenviron. Eng., 127(6), 521-529 
1 Nguyen, V. T., Rujikiatkamjorn, C., and Indraratna, B. (2013). "Analytical Solutions for

2 Filtration Process Based on Constriction Size Concept." J. Geotech. Geoenviron. Eng., 139(7),

3 1049-1061.

4 Raut, A. K. and Indraratna B. (2008). "Further advancement in filtration criteria through

5 constriction-based techniques.” J. Geotech. Geoenviron. Eng., 134(6), 883-887.

6 Reddi, L. N. (2003). Seepage in soils: principles and applications, J. Wiley, Hoboken, N.J.

7 Scott, B., Jaksa, M., and Kuo, Y. L. (2012) "Use of proctor compaction testing for deep fill

8 construction using impact rollers." Ground Improvement and Ground Control, B. Indraratna,

9 C. Rujikiatkamjorn, and J. S. Vinod, eds., Woloongong, Australia, 1107-1112.

10 Sherard, J. L. (1979). "Sinkholes in dams of coarse broadly graded soils." Proc. 13 ${ }^{\text {th }}$ Congr.

11 Large Dams, New Delhi., 2, 25-35.

12 Sherard, J., Dunnigan, L., and Talbot, J. (1984). "Basic properties of sand and gravel filters.” J.

13 Geotech. Eng., 110(6), 684-700.

14 Skempton, A. W., and Brogan, J. M. (1994). "Experiments on piping in sandy gravels."

15 Geotechnique, 44(3), 449-460.

16 Smith, J.L. and Bhatia, S.K., (2010). "Minimizing Soil Erosion with Geosynthetic Rolled

17 Erosion Control Products." Geo-Strata-Geo Inst. 14(4), 50-53.

18 Terzaghi, K. (1939). "Soil mechanics-A new chapter in engineering science.” J. Inst. of Civ.

19 Eng. (UK), 12(7), 106-141.

20 Trani, L. D. O. and Indraratna, B. (2010). “Assessment of Subballast Filtration under Cyclic

21 Loading." J. Geotech. Geoenviron. Eng, 136(11), 1519-1528.

22 Unites States Army Corps of Engineers USACE. (1953). "Investigation of filter requirements

23 for underdrains.” Tech. Memo. No. 3-360, U.S. Waterways Experiment Station, Vicksburg, 24 Miss. 
1 Wan, C. F., and Fell, R. (2008). "Assessing the potential of internal instability and suffusion in

2 embankment dams and their foundations.” J. Geotech. Geoenviron. Eng., 134(3), 401-407.

3 Xiao, M. and Shwiyhat, N. (2012). "Experimental investigation of the effects of suffusion on

4 physical and geomechanic characteristics of sandy soils." J. Geotech. Testing. 35(6), 890-900.

5 Xiao, M., Reddi, L.N., and Steinberg, S. (2006). "Effect of vibrations on pore fluid distribution

6 in porous media." Transport in Porous Media, 62(2), 187-204.

7 Zou, Y., Chen, Q., Chen, X., and Cui, P. (2013) "Discrete numerical modelling of particle

8 transport in granular filters." Comput. Geotech., 32(5), 340-57. 


\begin{tabular}{|c|c|c|c|c|c|c|c|c|c|}
\hline \multirow{2}{*}{ Sample } & \multicolumn{2}{|c|}{ Central layer $C_{u}$} & \multirow{2}{*}{$\begin{array}{c}\gamma_{s} \\
\left(\mathrm{kN} / \mathrm{m}^{3}\right)\end{array}$} & & $\begin{array}{c}i_{c r, t h} \\
\left(\underline{\gamma_{s}}-1\right)\end{array}$ & & \multicolumn{2}{|c|}{ Eroded fines, $(\%)$} & \multirow{2}{*}{$s,(\%)$} \\
\hline & Pre-test & Post-test & & & $\begin{array}{c}\text { Terzaghi } \\
\text { (1939) }\end{array}$ & & $\begin{array}{c}\text { Overall } \\
\text { sample }(f)\end{array}$ & $\begin{array}{c}\text { Central } \\
\text { layer }\left(f_{c}\right)\end{array}$ & \\
\hline C-1-R5 & 1.2 & 1.2 & 19.00 & 6.57 & 0.97 & 1.07 & 0 & 0 & 0 \\
\hline C-1-R50 & 1.2 & 1.2 & 19.92 & 52.3 & 1.07 & 1.18 & 0 & 0 & 0 \\
\hline C-1-R95 & 1.2 & 1.2 & 20.89 & 94.3 & 1.18 & 1.29 & 0 & 0 & 0 \\
\hline C-5-R5 & 5 & 5 & 18.91 & 6.94 & 0.94 & 1.0 & 0.19 & 0 & 0.50 \\
\hline C-5-R50 & 5 & 5 & 19.75 & 51.94 & 1.03 & 1.05 & 0.08 & 0 & 0.25 \\
\hline C-5-R95 & 5 & 5 & 20.80 & 92.5 & 1.13 & 1.10 & 0.03 & 0 & 0.00 \\
\hline C-10-R5 & 10 & 10 & 18.81 & 5.5 & 0.93 & 0.9 & 0.23 & 0 & 1.25 \\
\hline C-10-R50 & 10 & 10 & 19.82 & 47.2 & 1.01 & 1.0 & 0.14 & 0 & 0.74 \\
\hline C-10-R95 & 10 & 10 & 20.33 & 92.77 & 1.12 & 1.05 & 0.08 & 0 & 0.25 \\
\hline C-20-R5 & 20 & 23.7 & 21.00 & 6.1 & 0.92 & 0.45 & 7.64 & 11.2 & 1.97 \\
\hline C-20-R50 & 20 & 22.2 & 18.86 & 51.38 & 1.02 & 0.56 & 5.78 & 10.03 & 1.76 \\
\hline C-20-R70 & 20 & 20 & 19.77 & 71.1 & 1.07 & 0.90 & 3.54 & 2.39 & 1.49 \\
\hline C-20-R95 & 20 & 20 & 20.97 & 95.55 & 1.14 & 0.98 & 1.71 & 1.18 & 1.00 \\
\hline C-23-R5 & 23 & 18.2 & 18.94 & 7.35 & 0.93 & 0.62 & 6.42 & 5.32 & 1.61 \\
\hline C-23-R30 & 23 & 23 & 19.43 & 32.05 & 0.98 & 0.79 & 3.35 & 1.17 & 1.09 \\
\hline C-23-R60 & 23 & 23 & 20.12 & 63.2 & 1.05 & 0.94 & 1.91 & 0 & 0.72 \\
\hline C-23-R95 & 23 & 23 & 20.88 & 93.5 & 1.13 & 1.03 & 0.96 & 0 & 0.45 \\
\hline C-40-R5 & 40 & 10 & 19.30 & 6.3 & 0.92 & 0.28 & 14.40 & 15.27 & 1.99 \\
\hline C-40-R50 & 40 & 11.2 & 20.26 & 48 & 1.02 & 0.31 & 13.19 & 14.38 & 1.75 \\
\hline C-40-R95 & 40 & 12.5 & 21.35 & 92.5 & 1.14 & 0.37 & 11.47 & 14.07 & 1.73 \\
\hline
\end{tabular}

2 Note: Here, (C-\#-R@), $\gamma_{s}, R_{d}$, and $C_{u} f, f_{c} i_{c r, t h}, i_{c r, \exp }$ and s represent sample identity, 3 saturated unit weight, relative density, coefficient of uniformity, percentile eroded fines 4 from overall gradation $\left(=\frac{\text { Dry weight of eroded fines }}{\text { Total dry weight of sample }} \times 100\right)$, percentile eroded fines from 5 central layer (from Eq. 2), theoretical critical hydraulic gradient, experimental (observed) 6 critical gradient, and post-test settlement of samples respectively. 
Table 2. Comparison among predictions from five different geometrical methods and experimental results $(\mathrm{S}=\mathrm{Stable}$, and $\mathrm{U}=$ Unstable $)$

\begin{tabular}{|c|c|c|c|c|c|}
\hline \multirow[b]{2}{*}{ Sample ID } & \multicolumn{4}{|c|}{ Geometrical Assessments } & \multirow[b]{2}{*}{$\begin{array}{c}\text { Experimental } \\
\text { Result }\end{array}$} \\
\hline & $\begin{array}{l}\text { Kezdi } \\
(1979)\end{array}$ & $\begin{array}{l}\text { Sherard } \\
\text { (1979) }\end{array}$ & $\begin{array}{c}\text { Kenney } \\
\text { and Lau } \\
\text { (1985) }\end{array}$ & $\begin{array}{l}\text { Proposed } \\
\text { CP-CSD } \\
\text { Method }\end{array}$ & \\
\hline C-1-R5 & $\mathrm{S}$ & $\mathrm{S}$ & $\mathrm{S}$ & $\mathrm{S}$ & $\mathrm{S}$ \\
\hline C-1-R50 & $\mathrm{S}$ & $\mathrm{S}$ & $\mathrm{S}$ & $\mathrm{S}$ & $\mathrm{S}$ \\
\hline C-1-R95 & $\mathrm{S}$ & $\mathrm{S}$ & $\mathrm{S}$ & $\mathrm{S}$ & $\mathrm{S}$ \\
\hline C-5-R5 & $\mathrm{S}$ & $\mathrm{S}$ & $\mathrm{S}$ & $\mathrm{S}$ & $\mathrm{S}$ \\
\hline C-5-R50 & $\mathrm{S}$ & $\mathrm{S}$ & $\mathrm{S}$ & $\mathrm{S}$ & S \\
\hline C-5-R95 & $\mathrm{S}$ & $\mathrm{S}$ & $\mathrm{S}$ & $\mathrm{S}$ & $\mathrm{S}$ \\
\hline $\mathrm{C}-10-\mathrm{R} 5$ & $\mathrm{~S}$ & $\mathrm{~S}$ & $\mathrm{~S}$ & $\mathrm{~S}$ & $\mathrm{~S}$ \\
\hline C-10-R50 & $\mathrm{S}$ & $\mathrm{S}$ & $\mathrm{S}$ & $\mathrm{S}$ & $\mathrm{S}$ \\
\hline C-10-R95 & $\mathrm{S}$ & $\mathrm{S}$ & $\mathrm{S}$ & $\mathrm{S}$ & $\mathrm{S}$ \\
\hline $\mathrm{C}-20-\mathrm{R} 5$ & $S^{*}$ & $S^{*}$ & $S^{*}$ & $\mathrm{U}$ & $\mathrm{U}$ \\
\hline C-20-R50 & $\mathrm{S}^{*}$ & $\mathrm{~S}^{*}$ & $S^{*}$ & $\mathrm{U}$ & $\mathrm{U}$ \\
\hline C-20-R70 & $\mathrm{S}$ & $\mathrm{S}$ & $\mathrm{S}$ & $\mathrm{S}$ & $\mathrm{S}$ \\
\hline C-20-R95 & S & S & $\mathrm{S}$ & $\mathrm{S}$ & $\mathrm{S}$ \\
\hline C-23-R5 & $\mathrm{U}$ & $\mathrm{U}$ & $\mathrm{S}^{*}$ & $\mathrm{U}$ & $\mathrm{U}$ \\
\hline C-23-R30 & $\mathrm{U}^{* *}$ & $\mathrm{U}^{* *}$ & $\mathrm{~S}$ & S & $\mathrm{S}$ \\
\hline C-23-R60 & $\mathrm{U}^{* *}$ & $\mathrm{U}^{* *}$ & $\mathrm{~S}$ & $\mathrm{~S}$ & $\mathrm{~S}$ \\
\hline C-23-R95 & $\mathrm{U}^{* *}$ & $\mathrm{U}^{* *}$ & $\mathrm{~S}$ & $\mathrm{~S}$ & $\mathrm{~S}$ \\
\hline C-40-R5 & $\mathrm{U}$ & $\mathrm{S}^{*}$ & $\mathrm{U}$ & $\mathrm{U}$ & $\mathrm{U}$ \\
\hline C-40-R50 & $\mathrm{U}$ & $\mathrm{S}^{*}$ & $\mathrm{U}$ & $\mathrm{U}$ & $\mathrm{U}$ \\
\hline C-40-R95 & $\mathrm{U}$ & $\mathrm{S}^{*}$ & $\mathrm{U}$ & $\mathrm{U}$ & $\mathrm{U}$ \\
\hline
\end{tabular}
(safe) predictions. 
1 Table 3. Validation of proposed method with the published data

\begin{tabular}{|c|c|c|c|c|c|c|c|c|c|c|}
\hline \multirow{2}{*}{$\begin{array}{c}\text { Series } \\
\text { No }\end{array}$} & \multirow{2}{*}{ ID } & \multirow{2}{*}{ Reference } & \multirow{2}{*}{$\begin{array}{l}R_{d} \\
(\%)\end{array}$} & \multirow[b]{2}{*}{$C_{u}$} & \multirow{2}{*}{$\begin{array}{c}(H / F)_{\min } \\
\quad \text { For } F \\
\leq 30 \%\end{array}$} & \multirow[t]{2}{*}{$\begin{array}{c}P_{d} \\
(\%)\end{array}$} & \multirow{2}{*}{$\frac{D_{c 35}^{c}}{d_{85, S A}^{f}}$} & \multicolumn{3}{|c|}{ Assessments } \\
\hline & & & & & & & & $\begin{array}{c}\text { Kenney } \\
\text { and Lau, } \\
1985\end{array}$ & $\begin{array}{l}\text { Proposed } \\
\text { CP-CSD } \\
\text { Method }\end{array}$ & $\begin{array}{c}\text { Experimental } \\
\text { Result }\end{array}$ \\
\hline 1 & A & Kenney and & 90 & 30 & 1 & 20 & 0.90 & $\mathrm{~S}$ & $\mathrm{~S}$ & $\mathrm{U}$ \\
\hline 2 & $\mathrm{~A}_{\mathrm{s}}$ & Lau, 1985 & 90 & 24 & 0.9 & 25 & 0.98 & $\mathrm{U}$ & S & $\mathrm{S}$ \\
\hline 3 & $\mathrm{D}$ & & 90 & 30 & 0.5 & 20 & 1.28 & $\mathrm{U}$ & $\mathrm{U}$ & $\mathrm{U}$ \\
\hline 4 & $\mathrm{D}_{\mathrm{s}}$ & & 90 & 3.67 & 3 & 5 & 0.95 & S & $\mathrm{S}$ & $\mathrm{S}$ \\
\hline 5 & 1 & & 90 & 20 & 1.2 & 20 & 0.68 & S & $S$ & $S$ \\
\hline 6 & 2 & & 80 & 6 & 1.4 & 15 & 0.97 & S & $S$ & $S$ \\
\hline 7 & 3 & & 90 & 17.5 & 1.3 & 30 & 0.54 & S & $S$ & $S$ \\
\hline 8 & 20 & & 90 & 8 & 1.27 & 30 & 0.91 & $S$ & $S$ & $S$ \\
\hline 9 & 21 & & 90 & 6.2 & 1.2 & 30 & 0.44 & S & $S$ & $S$ \\
\hline 10 & 23 & & 90 & 20 & 6 & 5 & 0.95 & $S$ & $S$ & $S$ \\
\hline 11 & K & & 90 & 4 & 3.4 & 10 & 0.56 & S & S & $\mathrm{S}$ \\
\hline 12 & $\mathrm{X}$ & & 90 & 31.8 & 0.7 & 10 & 3.67 & $\mathrm{U}$ & $\mathrm{U}$ & $\mathrm{U}$ \\
\hline 13 & $\mathrm{Y}$ & & 90 & 50 & 0.9 & 20 & 2.35 & $\mathrm{U}$ & $\mathrm{U}$ & $\mathrm{U}$ \\
\hline 14 & $\mathrm{Y}_{\mathrm{s}}$ & & 90 & 40 & 0.9 & 15 & 1.86 & $\mathrm{U}$ & $\mathrm{U}$ & $\mathrm{U}$ \\
\hline 15 & F-1 & Indraratna and & 90 & 2.87 & 1.67 & 30 & 0.30 & $\mathrm{~S}$ & $\mathrm{~S}$ & $\mathrm{~S}$ \\
\hline 16 & F-2 & Vafai, 1997 & 90 & 2.87 & 2.33 & 30 & 0.25 & $S$ & $S$ & S \\
\hline 17 & Fine & Indraratna et & 50 & 1.28 & N/A & 30 & 0.30 & $S$ & $\mathrm{~S}$ & $S$ \\
\hline 18 & Medium & al., 1996 & 50 & 1.45 & N/A & 30 & 0.27 & S & $S$ & S \\
\hline 19 & Coarse & & 50 & 1.47 & N/A & 30 & 0.25 & $S$ & $\mathrm{~S}$ & $S$ \\
\hline 20 & F-1 (I) & Indraratna et al. & 70 & 3 & 2.33 & 30 & 0.32 & $\mathrm{~S}$ & $\mathrm{~S}$ & $\mathrm{~S}$ \\
\hline 21 & F-2 (I) & 2007 & 70 & 3 & 1.76 & 30 & 0.30 & $S$ & $S$ & $S$ \\
\hline 22 & F-4 (I) & & 70 & 1.2 & N/A & 30 & 0.22 & $S$ & $S$ & $S$ \\
\hline 23 & F-5 (I) & & 70 & 1.2 & N/A & 30 & 0.23 & $S$ & $S$ & $S$ \\
\hline 24 & F-6 (I) & & 70 & 1.2 & N/A & 30 & 0.23 & $\mathrm{~S}$ & $S$ & $\mathrm{~S}$ \\
\hline 25 & LF2 & Lafleur et al. & 70 & 11.6 & 1.11 & 30 & 0.51 & $S$ & $\mathrm{~S}$ & S \\
\hline 26 & LF3 & 1989 & 70 & 5.9 & 1.33 & 30 & 0.41 & $\mathrm{~S}$ & S & $\mathrm{S}$ \\
\hline 27 & LF4 & & 70 & 4 & 2 & 30 & 0.34 & S & S & S \\
\hline 28 & LF5 & & 70 & 3 & 9 & 10 & 0.33 & $\mathrm{~S}$ & $\mathrm{~S}$ & $\mathrm{~S}$ \\
\hline 29 & L1 & Locke et al. & 70 & 4 & 2.9 & 20 & 0.69 & S & S & $\mathrm{S}$ \\
\hline 30 & $\mathrm{~L} 2$ & 2001 & 70 & 3.7 & 2.72 & 25 & 0.46 & $\mathrm{~S}$ & S & $\mathrm{S}$ \\
\hline 31 & A (S) & Skempton and & 5 & 24 & 0.1 & 15 & 2.95 & $\mathrm{U}$ & $\mathrm{U}$ & $\mathrm{U}$ \\
\hline 32 & B (S) & Brogan, 1994 & 5 & 10 & 1 & 10 & 1.86 & $\mathrm{~S}$ & $\mathrm{U}$ & $\mathrm{U}$ \\
\hline 33 & $\mathrm{C}(\mathrm{S})$ & & 5 & 7 & 1.5 & 10 & 0.98 & $\mathrm{~S}$ & S & $\mathrm{S}$ \\
\hline 34 & $\mathrm{D}(\mathrm{S})$ & & 5 & 4.5 & 1.67 & 6 & 0.84 & $\mathrm{~S}$ & $\mathrm{~S}$ & $\mathrm{~S}$ \\
\hline 35 & NG1 & Nguyen et al. & 70 & 4 & N/A & 30 & 0.27 & $S$ & $\mathrm{~S}$ & $\mathrm{~S}$ \\
\hline 36 & NG2 & 2013 & 70 & 3.33 & N/A & 30 & 0.30 & $\mathrm{~S}$ & S & $\mathrm{S}$ \\
\hline 37 & NG3 & & 70 & 2.67 & 2.07 & 30 & 0.30 & $\mathrm{~S}$ & $S$ & $\mathrm{~S}$ \\
\hline 38 & NG4 & & 70 & 2 & 1.87 & 30 & 0.32 & $\mathrm{~S}$ & S & $\mathrm{S}$ \\
\hline 39 & NG5 & & 70 & 1.67 & 1.77 & 30 & 0.34 & $\mathrm{~S}$ & $S$ & $\mathrm{~S}$ \\
\hline 40 & NG6 & & 70 & 1.33 & 1.67 & 30 & 0.33 & $\mathrm{~S}$ & $\mathrm{~S}$ & $\mathrm{~S}$ \\
\hline 41 & IF1 & Indraratna et al. & 70 & 2.1 & N/A & 30 & 0.31 & $\mathrm{~S}$ & $\mathrm{~S}$ & $\mathrm{~S}$ \\
\hline 42 & IF2 & 2012 & 70 & 1.9 & N/A & 30 & 0.32 & $S$ & $S$ & $S$ \\
\hline 43 & IF3 & & 70 & 1.8 & N/A & 30 & 0.32 & $\mathrm{~S}$ & $\mathrm{~S}$ & $S$ \\
\hline 44 & IF4 & & 70 & 5.1 & 1.35 & 30 & 0.39 & $\mathrm{~S}$ & $\mathrm{~S}$ & $\mathrm{~S}$ \\
\hline 45 & IF5 & & 70 & 4.5 & 1.75 & 30 & 0.46 & $\mathrm{~S}$ & $\mathrm{~S}$ & $\mathrm{~S}$ \\
\hline 46 & IF6 & & 70 & 3.5 & 2.2 & 30 & 0.30 & $\mathrm{~S}$ & $\mathrm{~S}$ & $\mathrm{~S}$ \\
\hline
\end{tabular}




\begin{tabular}{|c|c|c|c|c|c|c|c|c|c|c|}
\hline 47 & G1-a & Honjo et al. & 65 & GG & 1 & 5 & 0.89 & $\mathrm{~S}$ & $\mathrm{~S}$ & $\mathrm{~S}$ \\
\hline 48 & G1-b & 1996 & 65 & GG & 1 & 10 & 0.45 & $\mathrm{~S}$ & $\mathrm{~S}$ & $\mathrm{~S}$ \\
\hline 49 & G1-c & & 65 & GG & 0.75 & 30 & 0.97 & $\mathrm{U}$ & $\mathrm{S}$ & $\mathrm{S}$ \\
\hline 50 & G1-d & & 65 & GG & 0.7 & 30 & 0.44 & $\mathrm{~S}$ & $\mathrm{~S}$ & $\mathrm{~S}$ \\
\hline 51 & $\mathrm{G} 2-\mathrm{a}$ & & 65 & GG & 2.7 & 20 & 0.75 & $\mathrm{~S}$ & $\mathrm{~S}$ & $\mathrm{~S}$ \\
\hline 52 & G2-b & & 65 & GG & 1.6 & 30 & 0.74 & $\mathrm{~S}$ & $\mathrm{~S}$ & $\mathrm{~S}$ \\
\hline 53 & G2-c & & 65 & GG & 1.3 & 30 & 0.37 & $\mathrm{~S}$ & $\mathrm{~S}$ & $\mathrm{~S}$ \\
\hline 54 & G3-a & & 65 & GG & 0 & 20 & 1.41 & $\mathrm{U}$ & $\mathrm{U}$ & $\mathrm{U}$ \\
\hline 55 & G3-b & & 65 & GG & 0 & 30 & 1.41 & $\mathrm{U}$ & $\mathrm{U}$ & $\mathrm{U}$ \\
\hline 56 & G3-c & & 65 & GG & 0.3 & 30 & 1.02 & $\mathrm{~S}$ & $\mathrm{U}$ & $\mathrm{U}$ \\
\hline 57 & G4-a & & 65 & GG & 0 & 20 & 1.99 & $\mathrm{U}$ & $\mathrm{U}$ & $\mathrm{U}$ \\
\hline 58 & G4-b & & 65 & GG & 0 & 30 & 1.96 & $\mathrm{U}$ & $\mathrm{U}$ & $\mathrm{U}$ \\
\hline 59 & G4-c & & 65 & GG & 0.3 & 30 & 1.02 & $\mathrm{U}$ & $\mathrm{U}$ & $\mathrm{U}$ \\
\hline 60 & SF1 & Sherard et al. & 70 & 6.3 & 1.83 & 30 & 0.75 & $\mathrm{~S}$ & $\mathrm{~S}$ & $\mathrm{~S}$ \\
\hline 61 & SF2 & $(1984 a)$ & 70 & 2.9 & 7.5 & 10 & 0.39 & $\mathrm{~S}$ & $\mathrm{~S}$ & $\mathrm{~S}$ \\
\hline 62 & SF3 & & 70 & 2.2 & 18 & 5 & 0.33 & S & $S$ & $\mathrm{~S}$ \\
\hline 63 & SF4 & & 70 & 1.9 & N/A & 30 & 0.28 & $\mathrm{~S}$ & $\mathrm{~S}$ & $\mathrm{~S}$ \\
\hline 64 & SF5 & & 70 & 1.8 & N/A & 30 & 0.25 & $\mathrm{~S}$ & $\mathrm{~S}$ & $\mathrm{~S}$ \\
\hline 65 & SF7 & & 70 & 1.1 & N/A & 30 & 0.19 & S & $S$ & $\mathrm{~S}$ \\
\hline 66 & SF8 & & 70 & 2.7 & 4 & 20 & 0.37 & $\mathrm{~S}$ & $\mathrm{~S}$ & $\mathrm{~S}$ \\
\hline 67 & SF9 & & 70 & 2.8 & 3.7 & 20 & 0.36 & $\mathrm{~S}$ & $\mathrm{~S}$ & $\mathrm{~S}$ \\
\hline 68 & SF10 & & 70 & 2.2 & N/A & 30 & 0.27 & S & $S$ & $\mathrm{~S}$ \\
\hline 69 & SF11 & & 70 & 1.5 & N/A & 30 & 0.28 & S & $S$ & $\mathrm{~S}$ \\
\hline 70 & SF12 & & 70 & 1.6 & N/A & 30 & 0.25 & S & $S$ & $\mathrm{~S}$ \\
\hline 71 & SF13 & & 70 & 1.1 & N/A & 30 & 0.20 & $\mathrm{~S}$ & $\mathrm{~S}$ & $\mathrm{~S}$ \\
\hline 72 & SF14 & & 70 & 1.2 & N/A & 30 & 0.25 & $\mathrm{~S}$ & $\mathrm{~S}$ & $\mathrm{~S}$ \\
\hline 73 & C-1-R5 & Current study & 6.6 & 1.2 & N/A & 30 & 0.48 & $\mathrm{~S}$ & $\mathrm{~S}$ & $\mathrm{~S}$ \\
\hline 74 & C-1-R50 & & 52.3 & 1.2 & N/A & 30 & 0.39 & $\mathrm{~S}$ & $\mathrm{~S}$ & $\mathrm{~S}$ \\
\hline 75 & C-1-R95 & & 94.3 & 1.2 & N/A & 30 & 0.29 & S & $S$ & $\mathrm{~S}$ \\
\hline 76 & C-5-R5 & & 6.9 & 5 & 1.4 & 30 & 0.93 & S & $S$ & $S$ \\
\hline 77 & C-5-R50 & & 51.9 & 5 & 1.4 & 30 & 0.76 & S & $S$ & $\mathrm{~S}$ \\
\hline 78 & C-5-R95 & & 92.5 & 5 & 1.4 & 30 & 0.59 & S & $S$ & $S$ \\
\hline 79 & C-10-R5 & & 5.6 & 10 & 1.07 & 30 & 0.84 & S & $S$ & $\mathrm{~S}$ \\
\hline 80 & C-10-R50 & & 47.2 & 10 & 1.07 & 30 & 0.68 & S & $S$ & $\mathrm{~S}$ \\
\hline 81 & C-10-R95 & & 92.8 & 10 & 1.07 & 30 & 0.53 & S & $S$ & $\mathrm{~S}$ \\
\hline 82 & C-20-R5 & & 6.1 & 20 & 0.73 & 30 & 1.28 & S & $\mathrm{U}$ & $\mathrm{U}$ \\
\hline 83 & C-20-R50 & & 51.4 & 20 & 0.73 & 30 & 1.05 & S & $\mathrm{U}$ & $\mathrm{U}$ \\
\hline 84 & C-20-R70 & & 71.1 & 20 & 0.73 & 30 & 0.93 & S & $S$ & $\mathrm{~S}$ \\
\hline 85 & C-20-R95 & & 95.6 & 20 & 0.73 & 30 & 0.78 & S & $S$ & $\mathrm{~S}$ \\
\hline 86 & C-23-R5 & & 7.4 & 23 & 1.06 & 15 & 1.11 & S & $\mathrm{U}$ & $\mathrm{U}$ \\
\hline 87 & C-23-R30 & & 32.1 & 23 & 1.06 & 15 & 0.96 & S & $S$ & $\mathrm{~S}$ \\
\hline 88 & C-23-R60 & & 63.2 & 23 & 1.06 & 15 & 0.83 & S & $S$ & $\mathrm{~S}$ \\
\hline 89 & C-23-R95 & & 93.5 & 23 & 1.06 & 15 & 0.69 & S & $S$ & $\mathrm{~S}$ \\
\hline 90 & C-40-R5 & & 6.3 & 40 & 0.7 & 30 & 1.64 & $\mathrm{U}$ & $\mathrm{U}$ & $\mathrm{U}$ \\
\hline 91 & C-40-R50 & & 48 & 40 & 0.7 & 30 & 1.32 & $\mathrm{U}$ & $\mathrm{U}$ & $\mathrm{U}$ \\
\hline 92 & C-40-R95 & & 92.5 & 40 & 0.7 & 30 & 1.02 & $\mathrm{U}$ & $\mathrm{U}$ & $\mathrm{U}$ \\
\hline
\end{tabular}

Note: Here, $P_{d}, D_{c 35}^{c}$, and $d_{85, S A}^{f}, K \& L$ represent division point on the PSD corresponding to $\left.2^{(H} / F\right)_{\text {min }}$, controlling constriction of the coarser half of PSD when divided at $P_{d}$, representative 3article size of the finer half of PSD corresponding to $85^{\text {th }}$ percentile finer obtained by plotting 4vith the surface area technique, and Kenney and Lau (1985)'s method respectively. N/A indicates 5nfinite $(\mathrm{H} / \mathrm{F})_{\min }$ values, representing highly stable samples for which $P_{d}$ at $30 \%$ was assumed. 


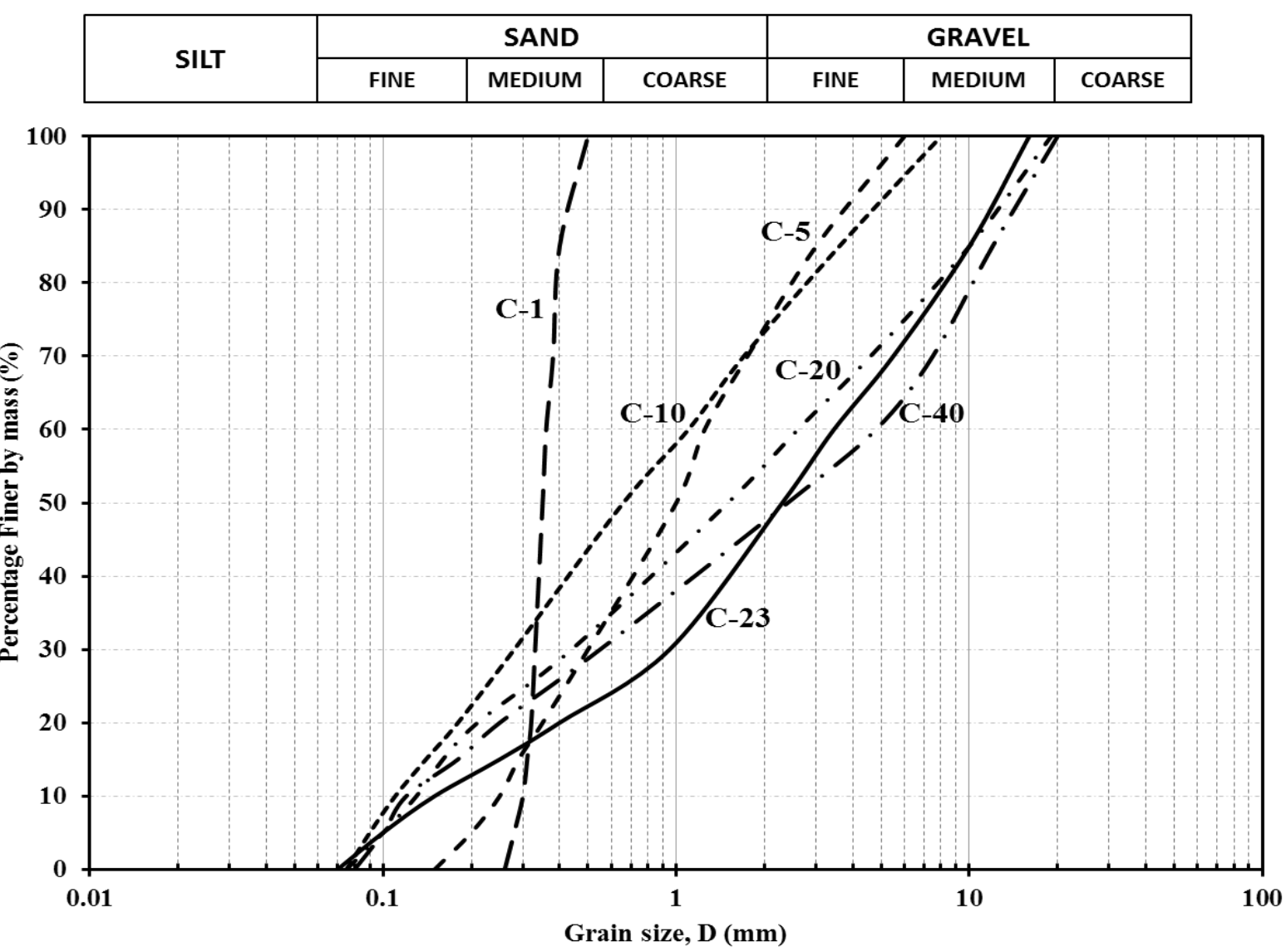

Fig. 1. PSDs for the soil gradations used in this study 


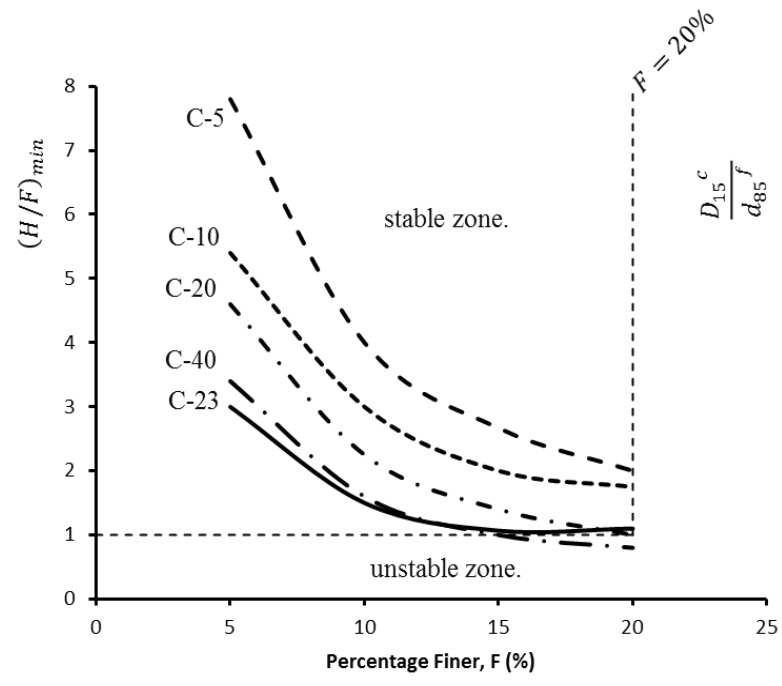

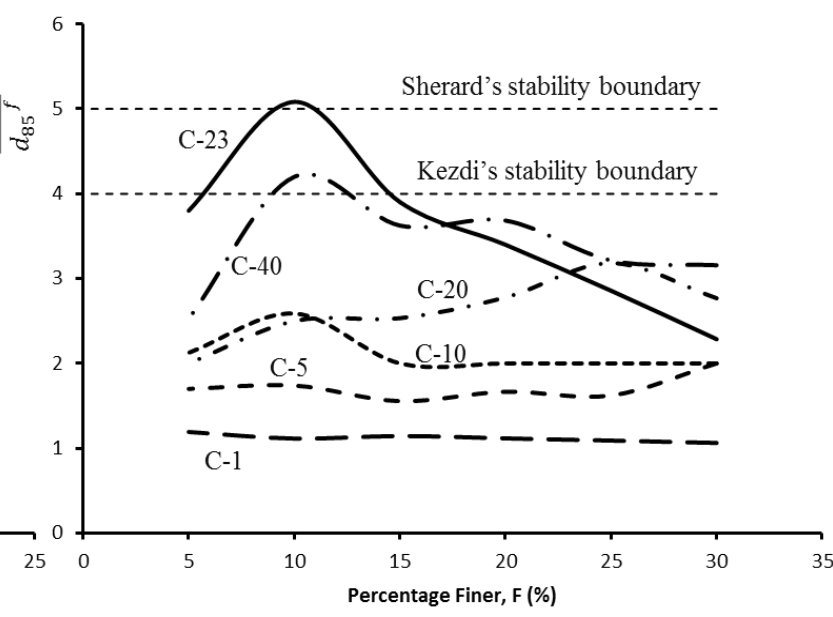

(b) Kezdi (1979) and Sherard (1979) Methods

2 Fig. 2. Geometrical assessments of internal instability potential for the current gradations

3 (Note: The $(\mathrm{H} / \mathrm{F})_{\min }$ value for $\mathrm{C}-1$ sample is infinite, thus it cannot be plotted in Fig. 2(a)) 4 


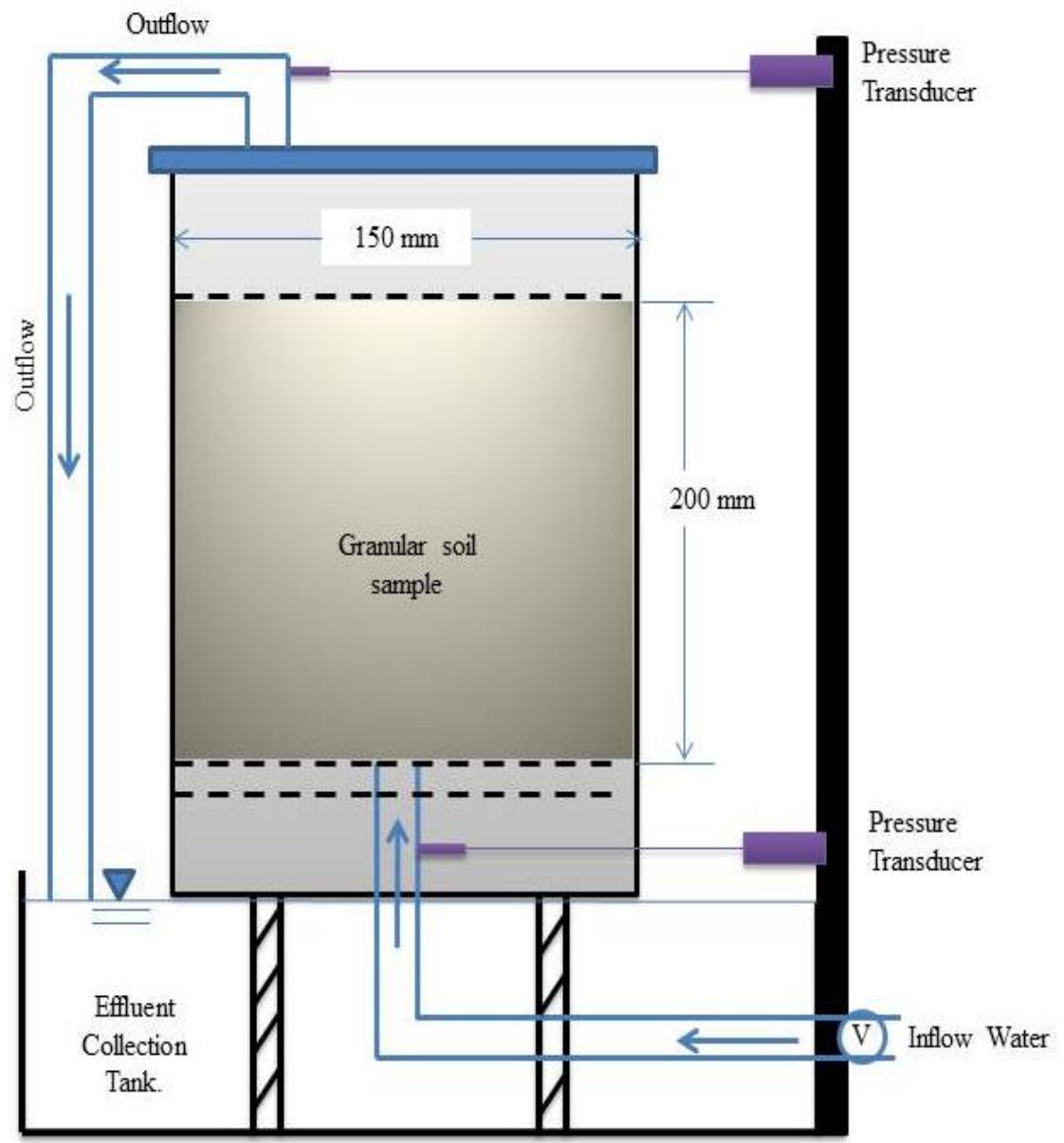

1

2 Fig. 3. Schematic illustration of test apparatus

3

4 


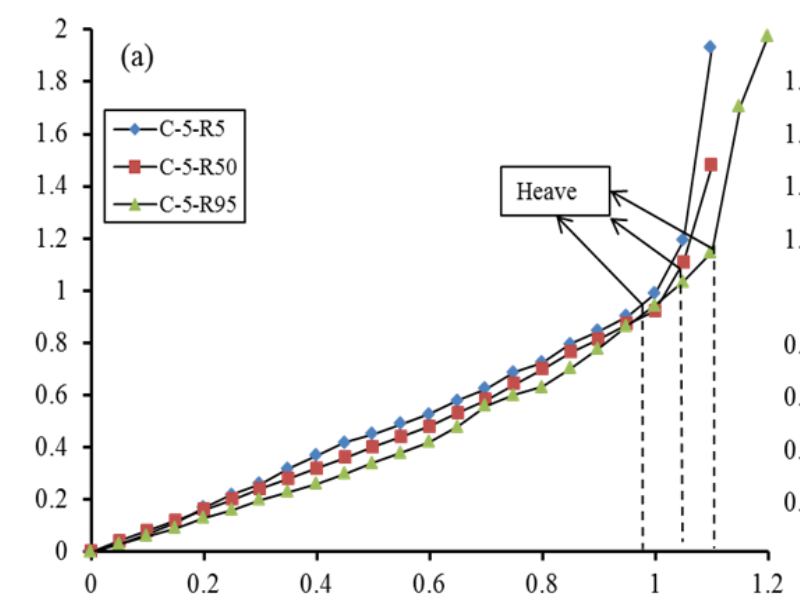

(b)
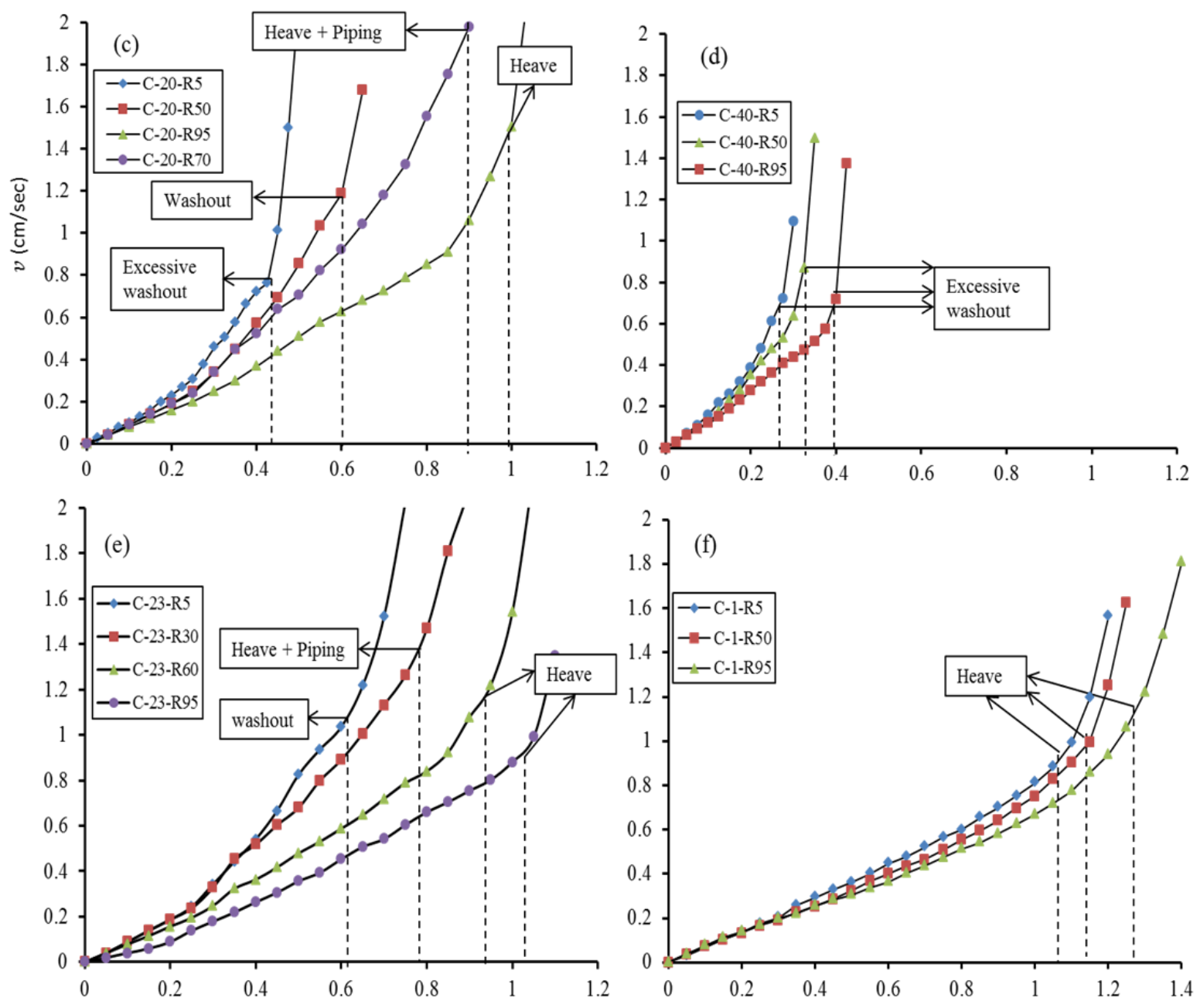

Applied Hydraulic Gradient, $i$

Fig. 4. Hydraulic gradients versus average flow velocity (a) sample C-5, (b) sample C-10, (c)

3 sample C-20, (d) sample C-40, (e) sample C-23, and (f) sample C-1 


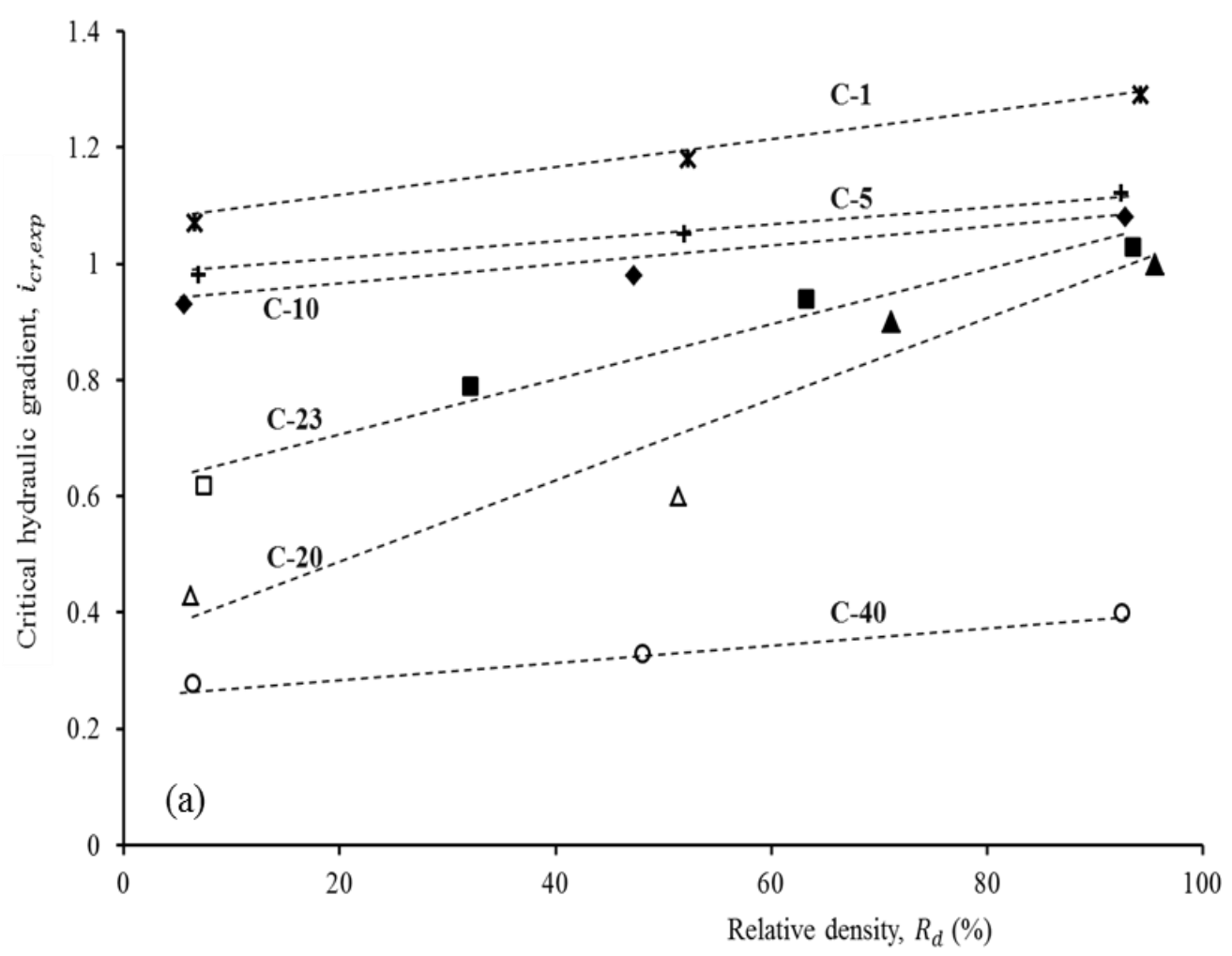

1

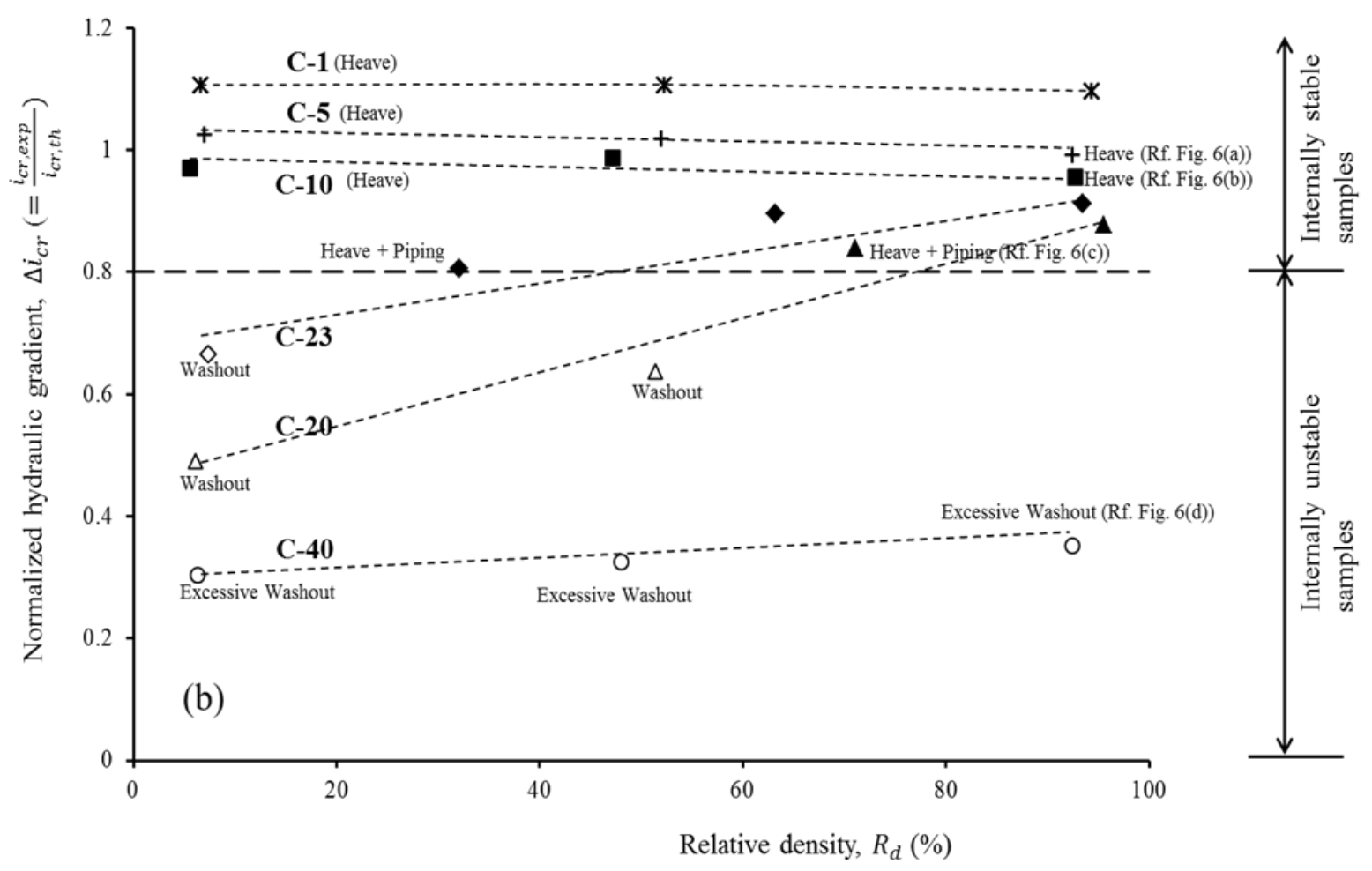

2

Fig. 5. Effect of Relative density on (a) observed critical hydraulic gradients, and (b)

4 normalized hydraulic gradients with respective mode of failure (solid symbols = stable;

5 hollow symbols $=$ unstable) 


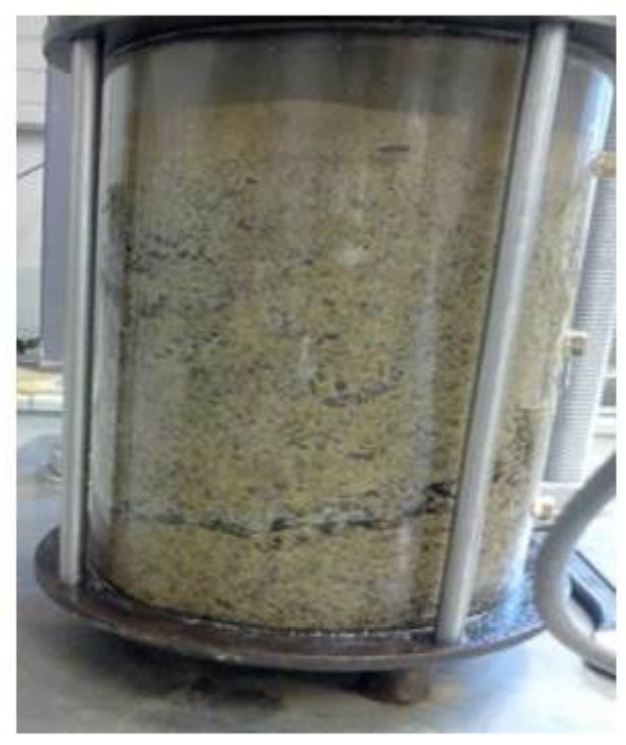

(a)

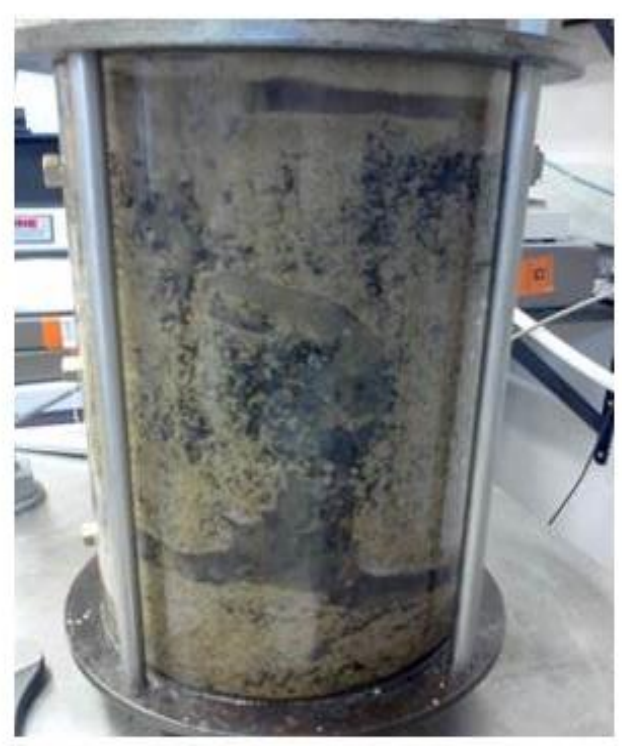

(c)

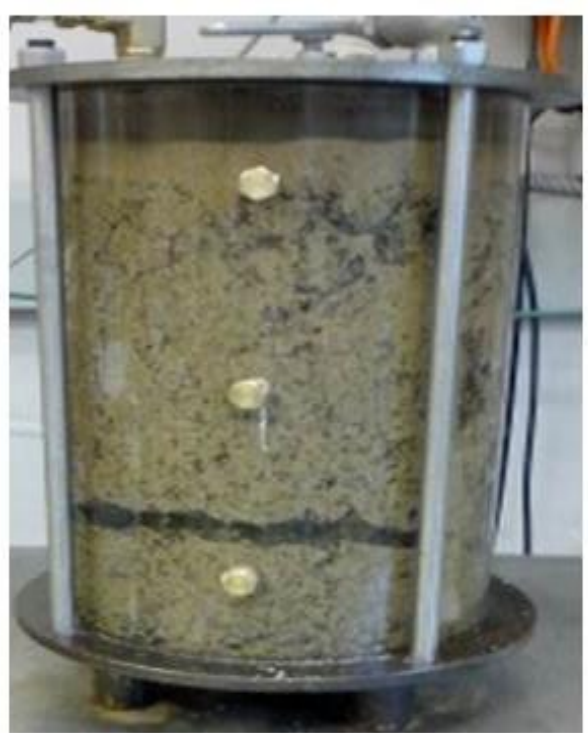

(b)

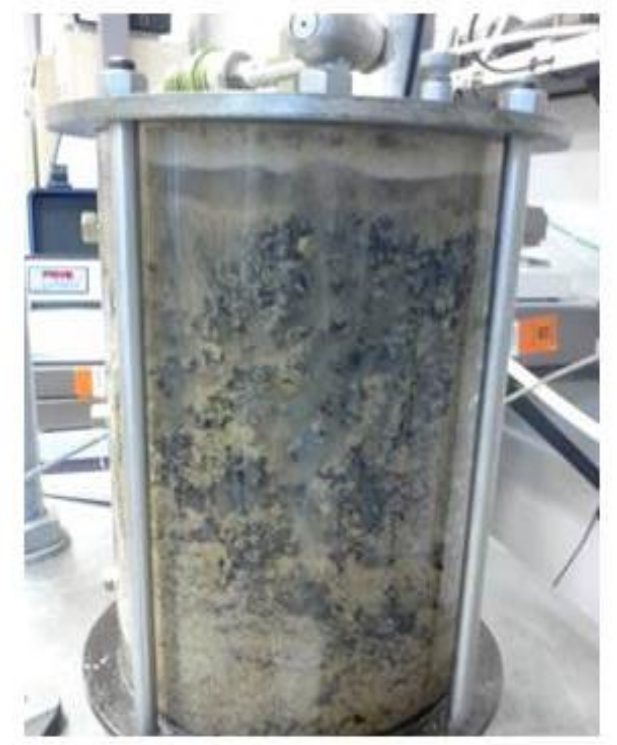

(d)

Fig. 6. Observations at the onset of failure during hydraulic tests; (a) Initiation of heave 3 failure in $\mathrm{C}-5$ at $\mathrm{R}_{\mathrm{d}}=92.5 \%(\mathrm{C}-5-\mathrm{R} 95)$, (b) Onset of heave in $\mathrm{C}-10$ at $\mathrm{R}_{\mathrm{d}}=92.77 \%$ (C-104 R95), (c) Initiation of piping failure in C-20 at $\mathrm{R}_{\mathrm{d}}=71.11 \%$ (C-20-R70), and (d) Onset of 5 washout in $\mathrm{C}-40$ at $\mathrm{R}_{\mathrm{d}}=92.5 \%(\mathrm{C}-40-\mathrm{R} 95)$ 


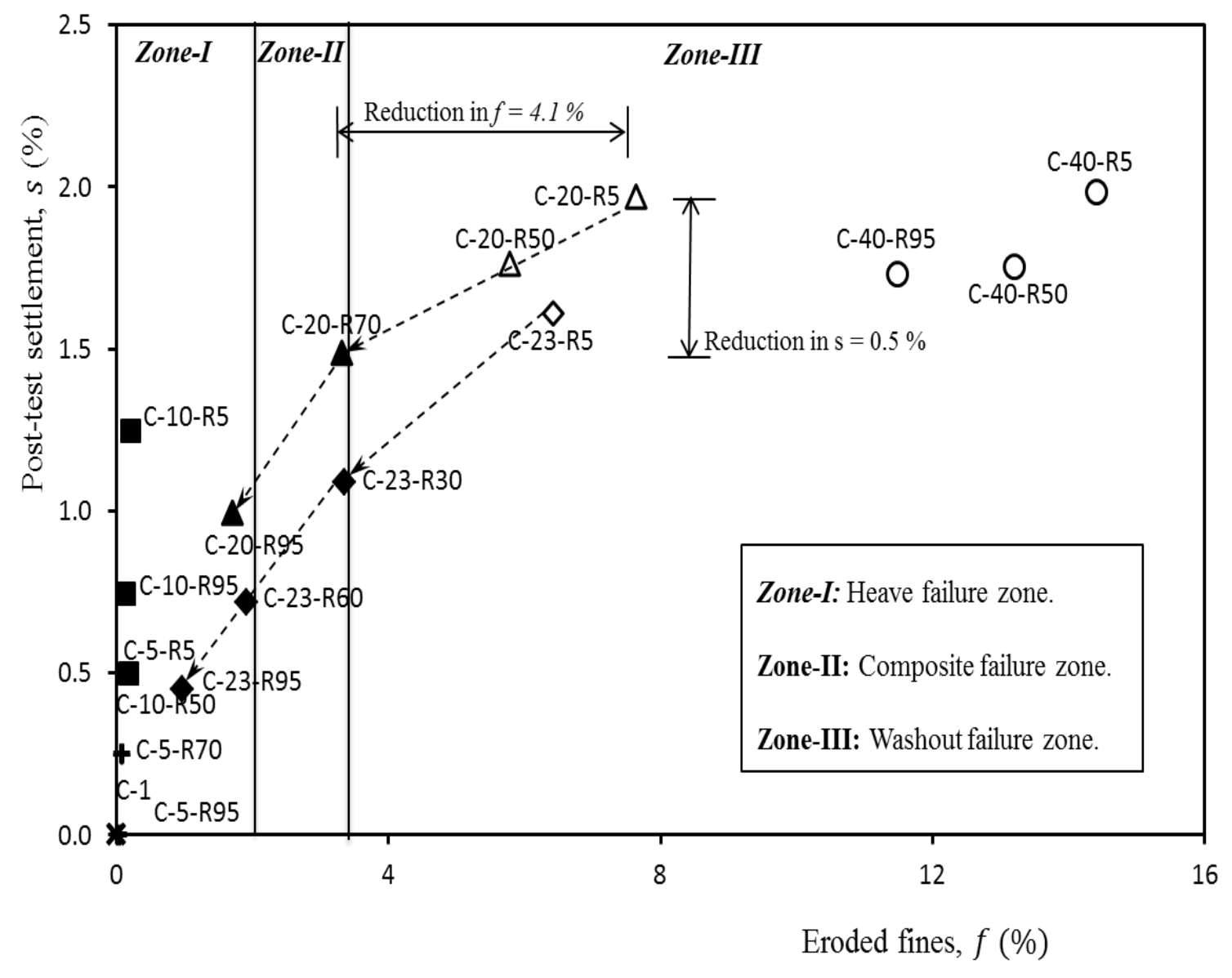

Fig. 7. Relationship between eroded fines and post-test settlement of test samples (solid $3 \quad$ symbols $=$ stable; hollow symbols $=$ unstable) 


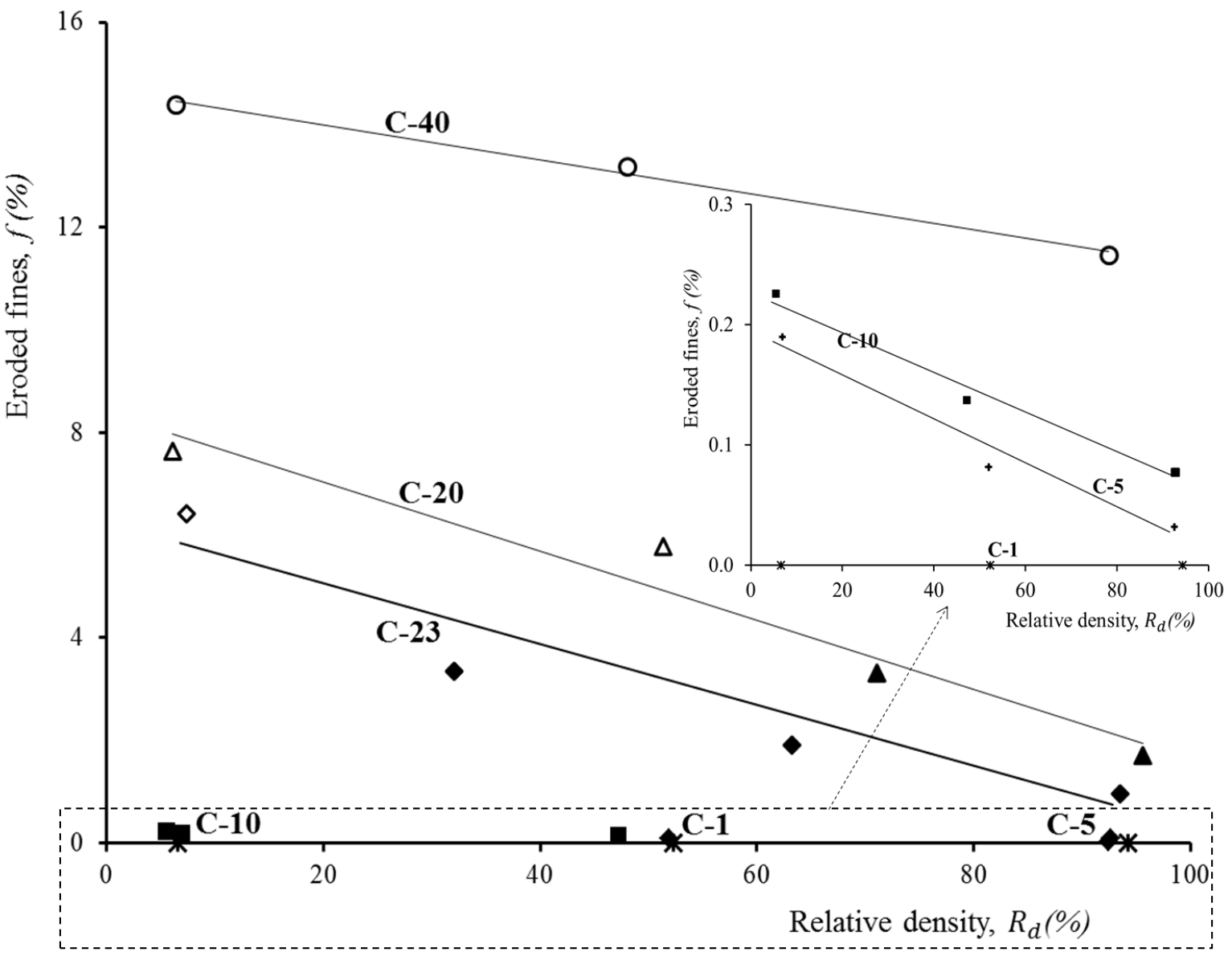

2 Fig. 8. Relationship between Relative density and percentile erosion from test samples (solid

$3 \quad$ symbols $=$ stable; hollow symbols $=$ unstable $)$ 


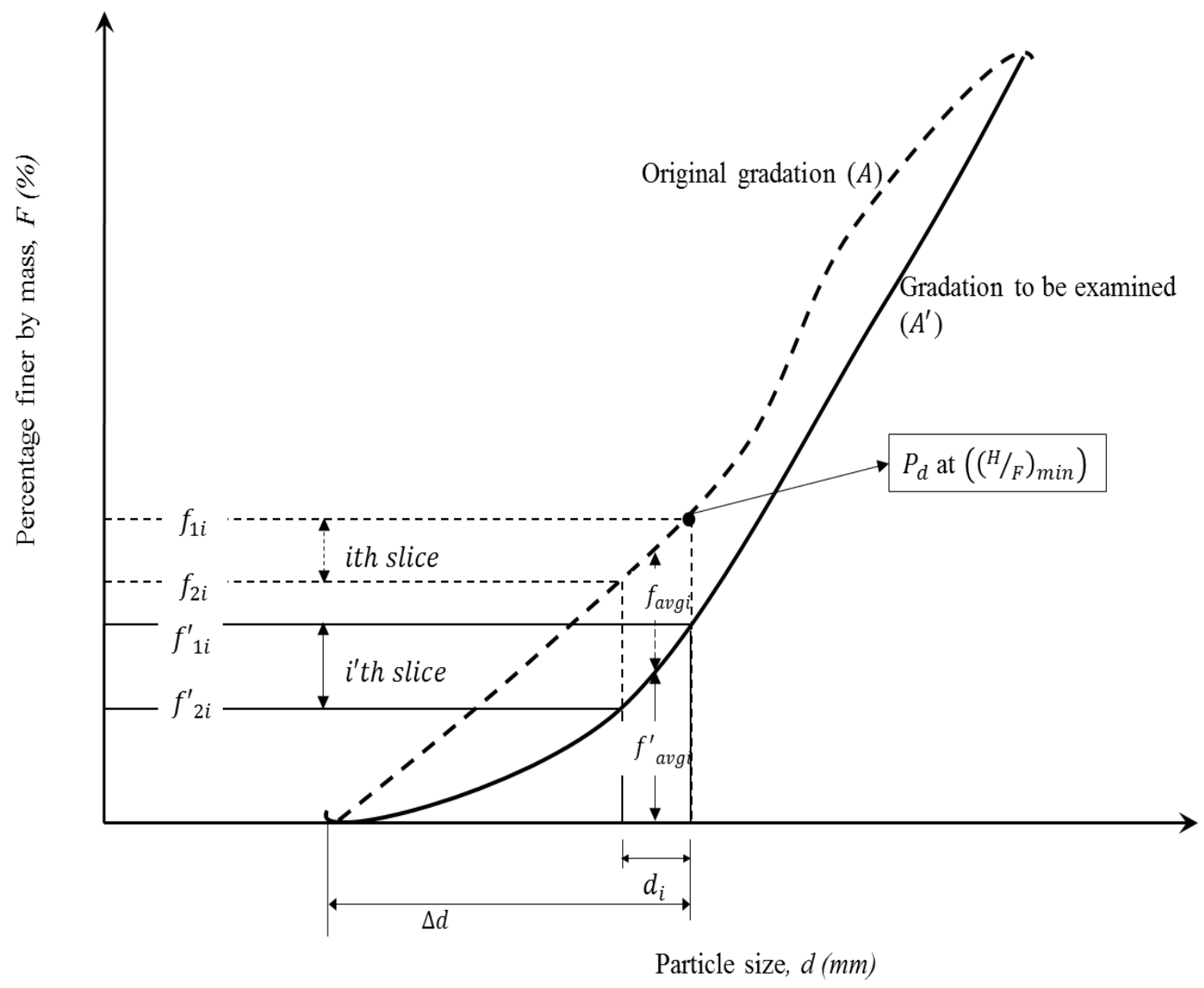

1

2FFig. 9. Illustration of proposed method for the estimation of eroded fines from curve analysis 


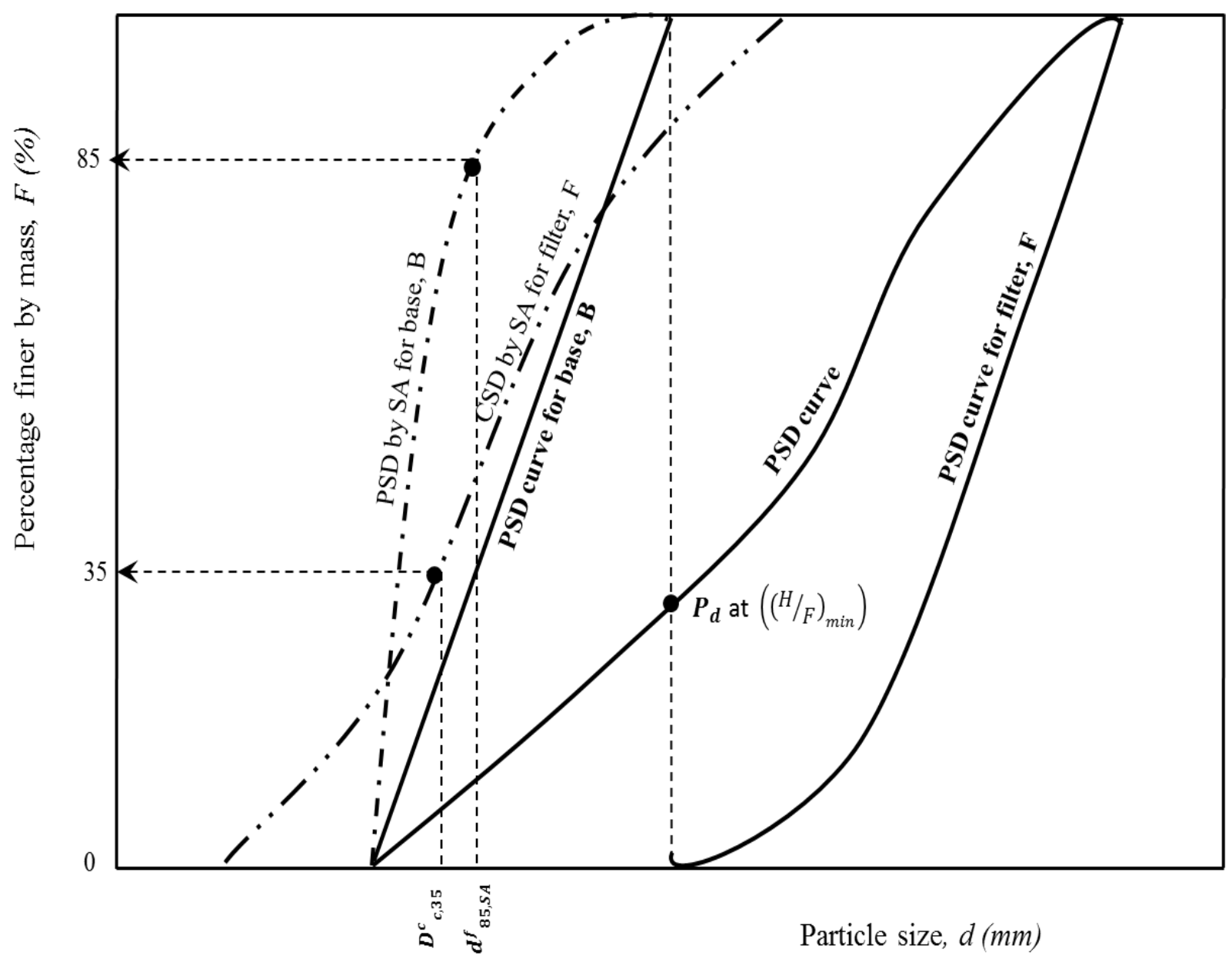

Fig. 10. Illustration of proposed CP-CSD method to assess internal instability potential of 3 granular filters ( $\mathrm{SA}=$ surface area technique) 


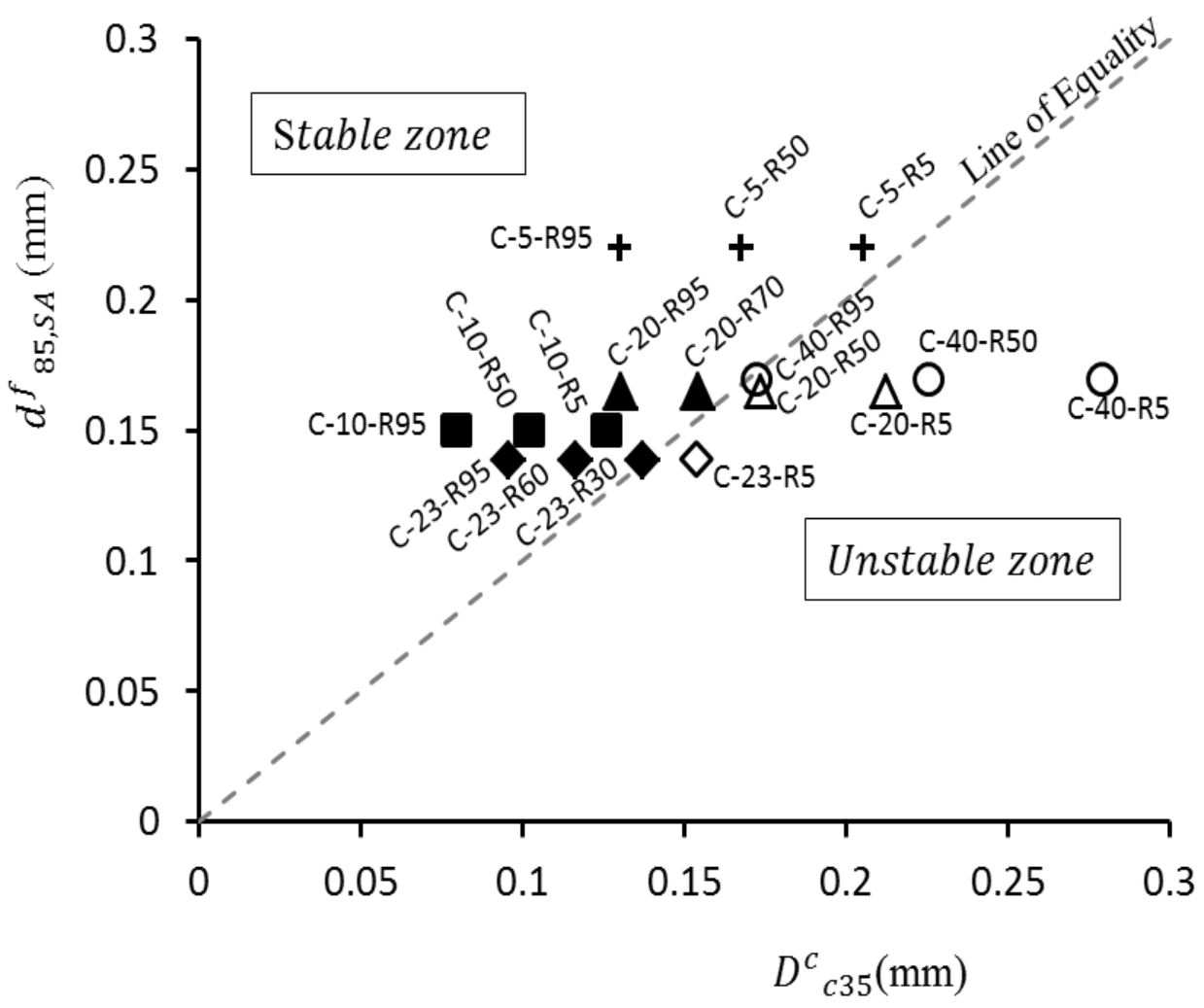

2 Fig. 11. Assessment of internal instability potential of test samples using proposed CP-CSD 3 method. (solid symbols $=$ stable; hollow symbols $=$ unstable $)$

4

5 

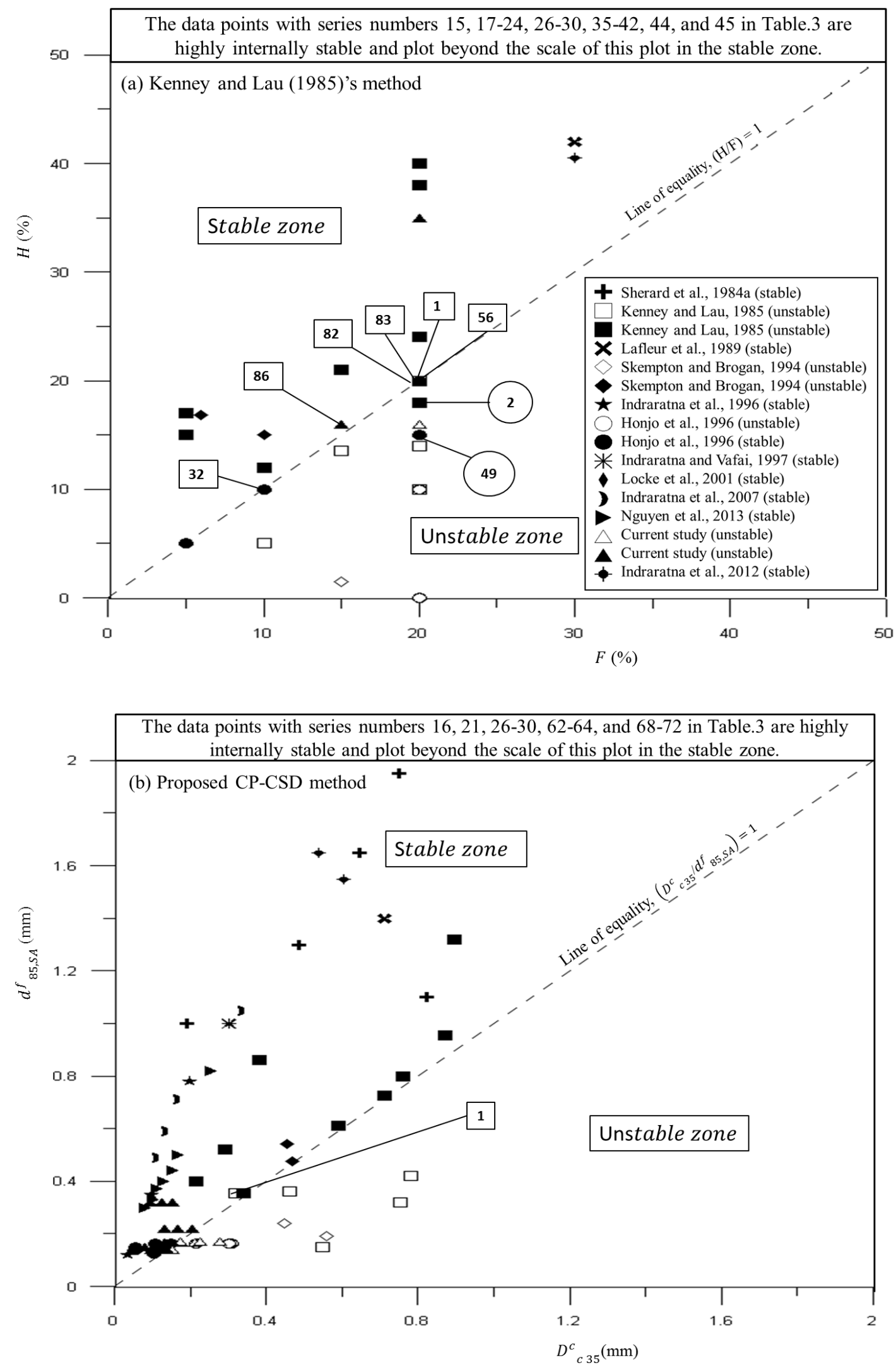

Fig. 12. Validation through selective data from Table 3, predictions from; (a) Kenney and 4 Lau (1985), and (b) Proposed CP-CSD method. Inconsistent predictions indicated by series 5 numbers in Table 3 (Test series Nos. in circles and rectangles indicate conservative and 6 unsafe predictions, respectively) 